\title{
Bats and Viruses
}

\section{Current Research and Future Trends}

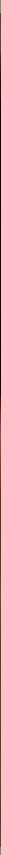

Edited by

Eugenia Corrales-Aguilar and Martin Schwemmle 


\section{Chapter 6 from:}

\section{Bats and Viruses}

\section{Current Research and Future Trends}

Edited by Eugenia Corrales-Aguilar and Martin Schwemmle

ISBN: 978-1-912530-14-4 (paperback)

ISBN: 978-1-912530-15-1 (ebook)

(C) Caister Academic Press

www.caister.com 


\title{
Genetic Diversity and Geographic Distribution of Bat-borne Hantaviruses
}

\section{Satoru Arai $^{1 *}$ and Richard Yanagihara ${ }^{2 *}$}

\author{
${ }^{1}$ Infectious Disease Surveillance Center, National Institute of Infectious Diseases, Shinjuku, Tokyo, Japan. \\ ${ }^{2}$ Pacific Center for Emerging Infectious Diseases Research, John A. Burns School of Medicine, University of Hawaii at \\ Manoa, Honolulu, HI, USA.
}

*Correspondence: arais@nih.go.jp and ryanagih@hawaii.edu

https://doi.org/10.21775/9781912530144.06

\section{Abstract}

The recent discovery that multiple species of shrews and moles (order Eulipotyphla, families Soricidae and Talpidae) from Europe, Asia, Africa and/or North America harbour genetically distinct viruses belonging to the family Hantaviridae (order Bunyavirales) has prompted a further exploration of their host diversification. In analysing thousands of frozen, RNAlater ${ }^{\circledast}$-preserved and ethanol-fixed tissues from bats (order Chiroptera) by reverse transcription polymerase chain reaction (RT-PCR), ten hantaviruses have been detected to date in bat species belonging to the suborder Yinpterochiroptera (families Hipposideridae, Pteropodidae and Rhinolophidae) and the suborder Yangochiroptera (families Emballonuriade, Nycteridae and Vespertilionidae). Of these, six hantaviruses are from Asia (Xuân Sơn virus and Đakrông virus in Vietnam; Láibīn virus in China and Myanmar; Huángpí virus and Lóngquán virus in China; and Quezon virus in the Philippines); three are from Africa (Mouyassué virus in Côte d'Ivoire and Ethiopia; Magboi virus in Sierra Leone; and Makokou virus in Gabon); and one from Europe (Brno virus in the Czech Republic). Molecular identification of many more bat-borne hantaviruses is expected. However, thus far, none of these newfound viruses has been isolated in cell culture and it is unclear if they cause infection or disease in humans. Future research must focus on myriad unanswered questions about the genetic diversity and geographic distribution, as well as the pathogenic potential, of bat-borne viruses of the family Hantaviridae.

\section{Introduction}

As recently as a decade ago, the single exception to the strict rodent association of hantaviruses was Thottapalayam virus, a long-unclassified virus originally isolated from the Asian house shrew (Suncus murinus) (Carey et al., 1971). Analysis of the genome of Thottapalayam virus strongly supported an ancient non-rodent host origin and an early evolutionary divergence from rodent-borne hantaviruses (Song et al., 2007a; Yadav et al., 2007). Equipped with this information and employing reverse transcription polymerase chain reaction (RT-PCR), genetically distinct hantaviruses were detected in multiple species of shrews (order Eulipotyphla, family Soricidae) from widely separated geographic regions in Asia, Europe, Africa and North America. In addition to challenging the conventional view that rodents are the sole or principal reservoirs of hantaviruses, the discovery of soricidborne hantaviruses suggested that moles (order Eulipotyphla, family Talpidae) might also harbour hantaviruses, and as predicted, several talpid-borne hantaviruses have been found in Europe, Asia and North America (Yanagihara et al., 2014).

Acquisition of new knowledge about the spatial and temporal distribution, host range and genetic diversity of hantaviruses in shrews and moles, and 
more recently in bats, has been made possible largely through the generosity of museum curators and field mammalogists, who willingly granted access to their archival tissue collections. The availability of such well-curated specimens provides strong justification for the continued long-term maintenance and near-term expansion of archival tissue repositories for future investigations and innovative applications (Dunnum et al., 2017).

Phylogenetic analyses of these newfound hantaviruses indicate at least four distinct clades, with the most divergent lineage comprising hantaviruses harboured by the European mole (Talpa europaea) (Kang et al., 2009c) and several bat species (Sumibcay et al., 2012; Weiss et al., 2012; Arai et al., 2013; Guo et al., 2013; Gu et al., 2014c; Xu et al., 2015; Arai et al., 2016b; Witkowski et al., 2016; Straková et al., 2017; Těśíková et al., 2017; Arai et al., 2019a; Arai et al., 2019b). On the basis of intensive phylogenetic analysis of the full-length $S$ - and M-genomic segments, a new taxonomic classification has been proposed, which includes four newly defined subfamilies in the family Hantaviridae (Maes et al., 2019). In addition, the realization that these Eulipotyphla- and Chiroptera-borne hantaviruses are more genetically diverse than those found in rodents, as well as the discovery of hantaviruslike sequences in fish and reptile hosts, suggests that the evolutionary history of the Hantaviridae is far more complex than previously conjectured. Thus, the dawn of a new era in hantavirology is focused on exploring the inconvenient evidence that rodents may not be the original mammalian hosts of primordial hantaviruses. Also, the once-growing complacency and indifference towards rodentborne hantaviruses is being replaced by renewed zeal to fill major gaps in our understanding about the ecology, transmission dynamics and pathogenic potential of these newly discovered, still-orphan hantaviruses, before the emergence of the next new hantavirus disease outbreak occurs (Yanagihara et al., 2015).

The history of research on this once-obscure group of rodent-borne viruses has been marked by rediscovery and new beginnings (Yanagihara et al., 2014). In this brief review, the genetic diversity and geographic distribution of hantaviruses from bats will be summarized in the context of hantaviruses harboured by rodents, shrews and moles to provide insights into their evolutionary origins and future risk and disease emergence.

\section{Taxonomy}

Previously classified in an unassigned order and in the genus Hantavirus of the family Bunyaviridae, hantaviruses have been recently reclassified and reassigned to a new family, designated Hantaviridae, in the order Bunyavirales (Adams et al., 2017; Maes et al., 2018). Viruses belonging to the four other genera formerly in the family Bunyaviridae (namely, Nairovirus, Orthobunyavirus, Phlebovirus, and Tospovirus) are now members of new viral families: Feraviridae, Fimoviridae, Jonviridae, Nairoviridae, Peribunyaviridae, Phasmaviridae, Phenuiviridae, and Tospoviridae.

ThefamilyHantaviridaehasbeenfurtherclassified into four subfamilies (Actantavirinae, Agantavirinae, Mammantavirinae and Repantavirinae) (Table 6.1). The subfamily Mammantavirinae comprises four genera (Loanvirus, Mobatvirus, Orthohantavirus and Thottimvirus), based on DEmARC analysis, using concatenated complete $\mathrm{S}$ and $\mathrm{M}$ amino acid-coding regions (Maes et al., 2019). Virus members of each genus in the subfamily Mammantavirinae, with their mammalian reservoir host category (rodent, shrew, mole and bat), are summarized in Table 6.1. In addition, recently published hantavirus-like sequences from fish and reptile, which are closely related and ancestral to hantaviruses harboured by mammals (Shi et al., 2018), have been classified into the newly created subfamilies of Actantavirinae and Agantavirinae and Repantavirinae, respectively (Table 6.1).

All rodent-borne hantaviruses belong to the genus Orthohantavirus, which also comprises nearly all of the genetically distinct hantaviruses recently detected in shrews and moles (Table 6.1). The exceptions are members of the genus Thottimvirus: Thottapalayam virus in the Asian house shrew (Suncus murinus) (Carey et al., 1971; Song et al., 2007a; Kang et al., 2011c) and Imjin virus in the Ussuri white-toothed shrew (Crocidura lasiura) (Song et al., 2009), as well as probably Uluguru virus in the Geata mouse shrew (Myosorex geata) (Kang et al., 2014) and Kilimanjaro virus in the Kilimanjaro mouse shrew (Myosorex zinki) (Kang et al., 2014). By contrast, all newfound hantaviruses 
Table 6.1 Taxonomic classification of viruses belonging to the family Hantaviridae and their reservoir host category

\begin{tabular}{|c|c|c|c|}
\hline Subfamily & Genus & Host & Virus name ${ }^{a}$ \\
\hline Actantavirinae & Actinovirus & Fish & Hagfish \\
\hline Agantavirinae & Agnathovirus & Fish & Batfish, Goosefish, Spikefish \\
\hline \multirow[t]{8}{*}{ Mammantavirinae } & Loanvirus & Bat & Brno, Huángpí, Lóngquán, Magboi, Mouyassué \\
\hline & Mobatvirus & Bat & Đakrông, Láibīn, Makokou, Quezon, Xuân Sơn \\
\hline & & Mole & Nova \\
\hline & Orthohantavirus & Rodent & $\begin{array}{l}\text { Andes, Bayou, Black Creek Canal, Cano Delgadito, Choclo, } \\
\text { Dàbiéshān, Dobrava, El Moro Canyon, Fugong, Hantaan, } \\
\text { Khabarovsk, Laguna Negra, Lúxī, Maporal, Montano, Necocli, } \\
\text { Prospect Hill, Puumala, Sangassou, Seoul, Sin Nombre, Thailand, } \\
\text { Tigray, Tula }\end{array}$ \\
\hline & & Shrew & $\begin{array}{l}\text { Ash River, Asikkala, Azagny, Boginia, Bowé, Cao Bằng, Jeju, Jemez } \\
\text { Springs, Kenkeme, Qian Hu Shan, Seewis, Tanganya, Yákèshí }\end{array}$ \\
\hline & & Mole & Asama, Bruges, Oxbow, Rockport \\
\hline & Thottimvirus & Shrew & Imjin, Kilimanjaro, Thottapalayam, Uluguru \\
\hline & & Mole & Dahonggou Creek \\
\hline Repantavirinae & Reptillovirus & Reptile & Gecko \\
\hline
\end{tabular}

airus names shown in italics indicate the presumptive taxonomic placement in the absence of full-length $\mathrm{S}$ - and M-segment sequences. The names for the viruses in the genera Actinovirus, Agnathovirus and Reptillovirus are tentative.

harboured by bats belong to the genera Loanvirus and Mobatvirus (Table 6.1).

To minimize unnecessary confusion, the viruses newly classified in the family Hantaviridae will be referred to in this chapter as hantaviruses, even if the genus Hantavirus no longer exists and is not part of the revised taxonomy. Members of the family Hantaviridae are enveloped viruses possessing a tripartite genome, comprising three single-stranded, negative-sense RNA segments, designated $S$ (small), M (medium), and L (large), which encode the nucleocapsid protein, the envelope glycoproteins ( $\mathrm{Gn}$ and $\mathrm{Gc}$ ), and the viral RNA-dependent RNA polymerase, respectively (Plyusnin et al., 1996; Guardado-Calvo and Rey, 2017).

\section{Hantavirus disease}

The clinical and public health significance of hantaviruses are attributed to two medically important syndromes, namely, haemorrhagic fever with renal syndrome (HFRS) (Myhrman, 1951; Smadel, 1953; Powell, 1954; Lähdevirta, 1971; Yanagihara and Gajdusek, 1988; Noh et al., 2013; Jiang et al., 2016; Zou et al., 2016) and hantavirus cardiopulmonary syndrome (HCPS) (Duchin et al., 1994; Ketai et al., 1994; Llah et al., 2018), which are caused by a few rodent-borne orthohantaviruses in Europe, Asia and the Americas (Lee et al., 1979; Brummer-Korvenkontio et al., 1980; Nichol et al., 1993; Jonsson et al., 2010; Jiang et al., 2017). Humans are usually infected with orthohantaviruses by the respiratory route with inhalation of aerosolized excretions or secretions (Tsai, 1987; Yanagihara, 1990). In general, person-to-person transmission does not occur, the rare exceptions being a few HCPS cases with Andes virus in Argentina and Chile (Padula et al., 1998; Toro et al., 1998; Martinez et al., 2005; Martinez-Valdebenito et al., 2014).

A fundamental epidemiological factor in HFRS and HCPS cases is exposure to environments contaminated with urine, faeces and/or saliva from infected rodents. Thus, outbreaks of HFRS and HCPS are often associated with encroachment of rodent habitats or irruptions of reservoir rodent populations with invasion of human dwellings. Although HFRS and HCPS cases have also resulted from seemingly trivial exposures, the intimate handling of rodents does not necessarily constitute sufficient exposure. That is, while mammalogists have frequent occupational contact with rodents and are presumably at increased risk, several seroepidemiological studies have indicated 
insignificant prevalence of orthohantavirus infections (Yanagihara et al., 1984; Vapalahti et al., 1995; Lundkvist et al., 2000; Fritz et al., 2002).

This has been corroborated in a more recent study, in which only four of 757 persons who had handled neotomine or sigmodontine rodents in North America exhibited serum IgG antibodies against Sin Nombre virus (Fulhorst et al., 2007). Also, during the height of the HCPS outbreak in the Four Corners region in 1993, forest and park service personnel showed no evidence of Sin Nombre virus infection (Vitek et al., 1996). By contrast, studies in Europe show clear associations between orthohantavirus infection and exposure to rodent excreta among certain high-risk occupation groups, such as animal trappers, forestry workers and farmers (Groen et al., 1995; Vapalahti et al., 1999; Grygorczuk et al., 2008; Mertens et al., 2011; Wróblewska-Łuczka et al., 2017; Wróblewska-Łuczkawroblewska et al., 2017), and individuals, such as hunters, whose recreational activities encroach on wildlife habitats (Deutz et al., 2003).

The principal symptoms and clinical features of both HFRS and HCPS include high fever, chills, headache, generalized myalgia, abdominal pain, and nausea and vomiting. Prominent shared characteristics of HFRS and HCPS also include thrombocytopenia (Connolly-Andersen et al., 2015) and vascular leakage, or increased endothelial cell permeability (Gorbunova et al., 2010). While HFRS varies in clinical severity, ranging from mild to severe and life threatening, with mortality ranging from $<1 \%$ to $\geq 15 \%$, depending on the specific orthohantavirus (Yanagihara and Gajdusek, 1988; Vaheri et al., 2013; Avšič-Županc et al., 2016), HCPS is generally severe, and despite intensive care treatment, has mortality rates of $25 \%$ or higher (Jonsson et al., 2010; Martinez et al., 2010; MacNeil et al., 2011). The clinical management of HFRS and HCPS is largely supportive, with careful fluid and electrolyte management and monitoring of cardiopulmonary and/or renal function. Dialysis may be required in some patients with severe HFRS. For HCPS patients, mechanical ventilation is frequently required, and other life-saving measures, such as extracorporeal membrane oxygenation, may be necessary (Duchin et al., 1994; Mertz et al., 2006).

\section{Rodents as reservoir hosts}

Orthohantaviruses are hosted by small mammals, unlike all other viruses in the order Bunyavirales, which are transmitted by arthropod vectors (mosquito, tick or sandfly). In particular, rodents (order Rodentia, families Muridae and Cricetidae) have long been known to serve as reservoir hosts of orthohantaviruses (Table 6.1). The seminal discovery that the striped field mouse (Apodemus agrarius) harboured Hantaan virus, the aetiological agent of Korean haemorrhagic fever (Lee et al., 1978), made possible the detection of Puumala virus, the agent of nephropathia epidemica, in the bank vole (Myodes glareolus) (Brummer-Korvenkontio et al., 1980). Subsequently, other murid rodent species, including the yellow-necked field mouse (Apodemus flavicollis) (Avšič-Županc et al., 1992), Korean field mouse (Apodemus peninsulae) (Yashina et al., 2001; Baek et al., 2006), Black Sea field mouse (Apodemus ponticus) (Klempa et al., 2008), brown rat (Rattus norvegicus) (Lee et al., 1982), and Chinese white-bellied rat (Niviventer confucianus) (Wang et al., 2000), as well as African wood mouse (Hylomyscus simus) in Guinea (Klempa et al., 2006) and Ethiopian white-footed mouse (Stenocephalemys albipes) in Ethiopia (Goüy de Bellocq et al., 2016), have been found to harbour genetically distinct orthohantaviruses.

Also, multiple cricetid rodent species of the subfamilies Arvicolinae, Sigmodontinae and Neotominae host orthohantaviruses. Examples include the meadow vole (Microtus pennsylvanicus) (Lee P-W et al., 1982, 1985), California vole (Microtus californicus) (Song W et al., 1995), common vole (Microtus arvalis) (Plyusnin et al., 1994), deer mouse (Peromyscus maniculatus) (Nerurkar et al., 1993; Nichol et al., 1993), white-footed mouse (Peromyscus leucopus) (Song et al., 1994), western harvest mouse (Reithrodontomys megalotis) (Hjelle et al., 1994), hispid cotton rat (Sigmodon hispidus) (Rollin et al., 1995), marsh rice rat (Oryzomys palustris) (Torrez-Martinez and Hjelle, 1995), Alston's cotton rat (Sigmodon alstoni) (Fulhorst et al., 1997), long-tailed rice rat (Oligoryzomys longicaudatus) (Levis et al., 1998), small-eared pygmy rice rat (Oligoryzomys microtis) (Powers et al., 1999), hairy-tailed bolo mouse (Necromys lasiurus) (Suzuki et al., 2004), large vesper mouse (Calomys callosus) (Levis et al., 2004), short-tailed 
cane mouse (Zygodontomys brevicauda) (Ruedas et al., 2004), and montane grass mouse (Akodon montensis) (Goodin et al., 2009).

Previously, the conventional view posited that each genetically distinct orthohantavirus was harboured by a single rodent species, with which it co-evolved. Mounting evidence refutes this overly simplistic paradigm and instead supports the concepts of host sharing and host switching. That is, the same orthohantavirus species may be hosted by more than one reservoir rodent species. For example, Tula virus has been reported in the common vole, southern vole (Microtus rossiaemeridionalis), field vole (Microtus agrestis), Altai vole (Microtus obscurus), European pine vole (Pitymys subterraneus) and Eurasian water vole (Arvicola amphibius) (Plyusnin et al., 1994; Song et al., 2002; Song et al., 2004; Schmidt-Chanasit et al., 2010; Schlegel et al., 2012a; Klempa et al., 2013b; Polat et al., 2018).

Host sharing seems to apply also to other rodentborne orthohantaviruses, such as Thailand virus, which has been detected in the greater bandicoot rat (Bandicota indica) (Elwell et al., 1985; Blasdell et al., 2011) and lesser bandicoot rat (Bandicota savilei) in Thailand (Pattamadilok et al., 2006), Asian house rat (Rattus tanezumi) in Indonesia (Plyusnina et al., 2009) and Singapore (Johansson et al., 2010), and black rat (Rattus rattus) in Madagascar (Reynes et al., 2014; Raharinosy et al., 2018). Moreover, genetic variants of Puumala virus, designated Hokkaido virus and Muju virus, have been reported in the grey red-backed vole (Myodes rufocanus) in Japan (Kariwa et al., 1995) and Russia (Yashina et al., 2015), northern red-backed vole (Myodes rutilus) in Russia (Yashina et al., 2015) and royal vole (Myodes regulus) in Korea (Song K-J et al., 2007; Lee JG et al., 2014).

Apart from examples of the same orthohantavirus species being harboured by multiple rodent species, the same rodent species can also host more than one orthohantavirus species. Examples include the field vole which hosts Tula virus in Europe and a newly discovered orthohantavirus, named Tatenale virus, in the United Kingdom (Pounder et al., 2013); and the striped field mouse, which serves as the reservoir of Hantaan virus in Asia, also hosts the Kurkino and Saaremaa genotypes of DobravaBelgrade virus in Europe (Nemirov et al., 1999; Klempa et al., 2013a; Németh et al., 2013).

\section{Shrews and moles as reservoir hosts}

Although the isolation of Thottapalayam virus from an Asian house shrew predated the isolation of prototype Hantaan virus, and despite early reports of HFRS antigens in tissues of the Eurasian common shrew (Sorex araneus), Eurasian water shrew (Neomys fodiens) and European mole in Russia (Gavrilovskaya et al., 1983; Tkachenko et al., 1983) and the former Yugoslavia (Gligić et al., 1992), shrews and moles (order Eulipotyphla, families Soricidae and Talpidae) have generally been dismissed as being unimportant in the phylogeography and evolution of hantaviruses.

However, guided by these long-ignored historical accounts and emboldened by the isolation of a novel hantavirus, named Imjin virus from the Ussuri white-toothed shrew captured along the Imjin River, near the demilitarized zone in the Republic of Korea (Song et al., 2009; Gu et al., 2011), an aggressive search was launched for hantavirus RNA, using a brute-force RT-PCR approach based on labour-intensive, time-consuming and trial-by-error oligonucleotide design. In analysing total RNA, extracted from more than 1500 tissues from 50 shrew species collected in Europe, Asia, North America and Africa, between 1982 and 2012, multiple genetically distinct soricid-borne orthohantaviruses have been detected (Table 6.1). These include Seewis virus in the Eurasian common shrew in Switzerland (Song et al., 2007b), Hungary and Finland (Kang et al., 2009a), Russia (Yashina et al., 2010) and Poland (Gu et al., 2014b); Ash River virus in the masked shrew (Sorex cinereus) and Jemez Springs virus in the dusky shrew (Sorex monticolus) in the USA (Arai et al., 2008a); Kenkeme virus in the flat-skulled shrew (Sorex roboratus) (Kang et al., 2010) and Artybash virus in the Laxmann's shrew (Sorex caecutiens) (Arai et al., 2016a) in Russia; Sarufutsu virus in the long-clawed shrew (Sorex unguiculatus) in Japan (S. Arai et al., unpublished data); Cao Bằng virus in the Chinese mole shrew (Anourosorex squamipes) in Vietnam (Song et al., 2007c) and Taiwanese mole shrew (Anourosorex yamashinai) in Taiwan ( $\mathrm{Gu}$ et al., 2016a); Camp Ripley virus in the northern short-tailed shrew (Blarina brevicauda) in the USA (Arai et al., 2007); Boginia virus in the Eurasian water shrew in Poland (Gu et al., 2013a); Bowé virus in the Doucet's musk 
shrew (Crocidura douceti) in Guinea (Gu et al., 2013b); Azagny virus in the West African pygmy shrew (Crocidura obscurior) in Côte d'Ivoire (Kang et al., 2011b); and Jeju virus in the Asian lesser white-toothed shrew (Crocidura shantungensis) in Korea (Arai et al., 2012). By contrast, Uluguru virus in the geata mouse shrew and Kilimanjaro virus in the Kilimanjaro mouse shrew in Tanzania (Kang et al., 2014) appear to be more closely related to Thottapalayam virus and Imjin virus, which have been classified in the genus Thottimvirus (Table 6.1).

Host sharing or spillover has also been found for soricid-borne orthohantaviruses. Examples include Seewis virus in the Eurasian common shrew and Eurasian pygmy shrew (Sorex minutus) in the Czech Republic and Germany (Schlegel et al., 2012b) and in Poland ( $\mathrm{Gu}$ et al., 2014b). Also, Seewis virus has been detected in the tundra shrew (Sorex tundrensis) and large-toothed Siberian shrew (Sorex daphaenodon) in Russia (Yashina et al., 2010) and in the Mediterranean water shrew (Neomys anomalus) in Austria (N. Nowotny, unpublished data) and Poland ( $\mathrm{Gu}$ et al., 2014b). Moreover, Jemez Springs virus, which is harboured by the dusky shrew, has been found in the vagrant shrew (Sorex vagrans), Trowbridge's shrew (Sorex trowbridgii) and American water shrew (Sorex palustris) in the USA (H.J. Kang et al., unpublished data).

In addition, other investigators have reported soricid-borne orthohantaviruses, including Seewis virus in the Eurasian common shrew in Austria (N. Nowotny, unpublished data), Finland (Ling et al., 2014), Germany (Schlegel et al., 2012b; Obiegala et al., 2017), Slovakia (Schlegel et al., 2012b) and Slovenia (Korva et al., 2013; Resman et al., 2013); Tanganya virus in the Therese's shrew (Crocidura theresae) in Guinea (Klempa et al., 2007); Qian Hu Shan virus in the greater striped-back shrew (Sorex cylindricauda) (Zuo et al., 2014) and Yákèshí virus in the taiga shrew (Sorex isodon) (Guo et al., 2013) in China; and Asikkala virus in the Eurasian pygmy shrew in the Czech Republic and Germany (Radosa et al., 2013). Moreover, Kenkeme virus was found to co-circulate with Hantaan and Khabarovsk viruses in Bolshoy Ussuriysky Island, in China (Wang et al., 2014).

Testing more than 600 tissue samples from 12 of the approximately 40 extant mole species has yielded seven genetically distinct hantaviruses:
Asama virus in the Japanese shrew mole (Urotrichus talpoides) from Japan (Arai et al., 2008b); Oxbow virus in the American shrew mole (Neurotrichus gibbsii) (Kang et al., 2009b) and Rockport virus in the eastern mole (Scalopus aquaticus) (Kang et al., 2011a) from the USA; Nova virus in the European mole from Hungary (Kang et al., 2009c), France (Gu et al., 2014a), Poland (Gu et al., 2014b) and Belgium (Laenen et al., 2018); Bruges virus in the European mole from Belgium and United Kingdom (Laenen et al., 2018); Asturias virus in the Iberian mole (Talpa occidentalis) from Spain (Gu et al., 2016c); and Dahonggou Creek virus in the long-tailed mole (Scaptonyx fusicaudus) from China (Kang et al., 2016). As in rodents, the same talpid host can harbour more than one hantavirus species, as exemplified by the European mole, which hosts Nova virus and Bruges virus in Belgium (Laenen et al., 2018) and the Iberian mole, which appears to harbour Asturias virus, Bruges virus and Nova virus in Spain (Gu et al., 2016c).

Because many mole species have been unavailable for testing and sample sizes were small, numbering fewer than 10 individuals for many of the species tested, the list of seven probably represents a gross underestimation of the actual number of talpid-borne hantaviruses. More targeted searches for hantavirus RNA in mole species, such as the Altai mole (Talpa altaica), blind or Mediterranean mole (Talpa caeca), Caucasian mole (Talpa caucasica), Roman mole (Talpa romana) and Balkan mole (Talpa stankovici), will likely lead to the discovery of additional hantaviruses and provide insights into host-switching events.

Nova virus, which represents among the most highly divergent lineages (Kang et al., 2009c), has been classified in the genus Mobatvirus with several hantaviruses harboured by bats (Table 6.1). Recent studies have indicated high prevalence of Nova virus infection exceeding 50\% in European moles from France and Poland, suggesting efficient enzootic virus transmission and a well-established, long-standing reservoir host-mobatvirus relationship (Gu et al., 2014a; Gu et al., 2014b). Much like Seewis virus, which is widespread in the Eurasian common shrew throughout Europe, Nova virus probably occurs throughout the vast distribution of the European mole. 


\section{Bats as reservoir hosts}

Bats (order Chiroptera) represent the second largest order of mammals, with more than 1200 species or approximately $20 \%$ of all classified mammal species worldwide. Bats are found in all continents, except Antarctica. They are the only mammals capable of controlled and sustained flight. While most bats are insectivorous or frugivorous, three extant bat species, which are all native to the Americas, feed exclusively on the blood of birds or mammals. Bats serve as natural reservoirs of many microbial pathogens, and their mobility through flight, longevity and social structures contribute to the transmission and spread of zoonotic diseases.

The order Chiroptera was formerly divided in two suborders: Megachiroptera and Microchiroptera. However, due to the paraphyly of the Microchiroptera, a new taxonomic nomenclature has been proposed, comprising the suborder Yinpterochiroptera or Vespertilioniformes (megabats or fruit bats in the family Pteropodidae in Megachiroptera and a few Microchiroptera families) and the suborder Yangochiroptera or Pteropodiformes (the remaining Microchiroptera families) (Teeling, 2009). Irrespective of the classification, bat species in both suborders have been found to host viruses in the newly created genera of Loanvirus and Mobatvirus, within the subfamily Mammantavirinae, of the family Hantaviridae, suggesting that primordial hantaviruses may have emerged in an early common ancestor of bats.

Despite the more than 3000 tissue samples from approximately 100 bat species, representing 11 families (Emballonuridae, Hipposideridae, Megadermatidae, Miniopteridae, Molossidae, Mormoopidae, Nycteridae, Phylostomidae, Pteropodidae, Rhinopholidae, and Vespertilionidae), tested by RT-PCR, only 10 bat-borne hantaviruses have hitherto been reported (Table 6.2). Within the suborder Yinpterochiroptera, hantaviruses have been reported in bat species belonging to three

Table 6.2 Summary of bat-borne loanviruses and mobatviruses in the family Hantaviridae ${ }^{a}$

\begin{tabular}{|c|c|c|c|c|c|c|}
\hline Authors & $\begin{array}{l}\text { Tissues } \\
\text { collected }\end{array}$ & $\begin{array}{l}\text { Total } \\
\text { tested }\end{array}$ & Genus species & Country & $\begin{array}{l}\text { RNA } \\
\text { positive }\end{array}$ & Virus name \\
\hline Sumibcay et al. (2012) & 2011-2012 & 213 & Neoromicia nanus & Côte d'Ivoire & $2 / 12$ & Mouyassué \\
\hline Weiss et al. (2012) & 2009-2011 & 417 & Nycteris hispida & Sierra Leone & $1 / 18$ & Magboi \\
\hline Arai et al. (2013) & 2012 & 51 & Hipposideros pomona & Vietnam & $1 / 5$ & Xuân Sơn \\
\hline \multirow[t]{4}{*}{ Guo et al. (2013) } & 2011-2012 & 605 & Rhinolophus monoceros & China & $1 / 4$ & Lóngquán \\
\hline & & & Rhinolophus affinis & China & $6 / 26$ & Lóngquán \\
\hline & & & Rhinolophus sinicus & China & $3 / 135$ & Lóngquán \\
\hline & & & Pipistrellus abramus & China & $1 / 5$ & Huángpí \\
\hline Gu et al. (2014c) & $1981-2012$ & 533 & Hipposideros pomona & Vietnam & $5 / 44$ & Xuân Sơn \\
\hline Xu et al. (2015) & 2012 & 32 & Taphozous melanopogon & China & $1 / 32$ & Láibīn \\
\hline Arai et al. (2016b) & 2008-2013 & 376 & Rousettus amplexicaudatus & Philippines & $1 / 15$ & Quezon \\
\hline Witkowski et al. (2016) & 2009 & 324 & Hipposideros ruber & Gabon & $1 / 123$ & Makokou \\
\hline Straková et al. (2017) & 2008-2013 & 53 & Nyctalus noctula & Czech Republic & $2 / 12$ & Brno \\
\hline Těšíková et al. (2017) & 2009-2014 & 85 & Neoromicia capensis & Ethiopia & $1 / 25$ & Mouyassué \\
\hline Arai et al. (2019a) & 2013-2015 & 121 & Taphozous melanopogon & Myanmar & $2 / 13$ & Láibīn \\
\hline Arai et al. (2019a) & 2013-2015 & 156 & Hipposideros cineraceus & Vietnam & $3 / 6$ & Xuân Sơn \\
\hline Arai et al. (2019b) & 2012-2015 & 215 & Aselliscus stoliczkanus & Vietnam & $1 / 2$ & Đakrông \\
\hline
\end{tabular}

aTotal number of bats tested: 3181 (representing 11 families) resulting in 32 positive bats by RT-PCR Yinpterochiroptera: Hipposideridae, Megadermatidae, Pteropodidae, Rhinopholidae.

Yangochiroptera: Emballonuridae, Miniopteridae, Molossidae, Mormoopidae, Nycteridae, Phylostomidae,

Vespertilionidae.

Unpublished data on approximately 2000 additional bats from Africa: Ponan virus in Neoromicia nanus from Côte d'Ivoire.

Lompole virus in unidentified bat species from Democratic Republic of Congo. 
phylogenetically distant families, namely Hipposideridae (Old World leaf-nosed bats), Rhinolophidae (horseshoe bats) and Pteropodidae (Old World fruit bats) (Arai et al., 2013; Guo et al., 2013; Gu et al., 2014c; Arai et al., 2016b; Witkowski et al., 2016; Arai et al., 2019a; Arai et al., 2019b), while within the suborder Yangochiroptera, bat species in the families Nycteridae (slit-faced or hollow-faced bats), Vespertilionidae (vesper bats) and Emballonuridae (sac-winged bats) have been shown to harbour hantaviruses (Sumibcay et al., 2012; Weiss et al., 2012; Xu et al., 2015; Straková et al., 2017; Těšíková et al., 2017; Arai et al., 2019a). The families Hipposideridae and Vespertilionidae are among the most speciose insectivorous bats, with member species distributed across Africa, Europe, Asia, the Americas and Australia. Their vast geographic distribution provides unlimited opportunities to search for other bat-associated hantaviruses.

To date, bat-borne hantaviruses include: Mouyassué virus in the banana pipistrelle (Neoromicia nanus) from Côte d'Ivoire (Sumibcay et al., 2012) and cape serotine (Neoromicia capensis) from Ethiopia (Těšíková et al., 2017); Magboi virus in the hairy slit-faced bat (Nycteris hispida) from Sierra Leone (Weiss et al., 2012); Xuân Sơn virus in the Pomona roundleaf bat (Hipposideros pomona) (Arai et al., 2013; Gu et al., 2014c) and ashy roundleaf bat or least leaf-nosed bat (Hipposideros cineraceus) (Arai et al., 2019a) from Vietnam; Đakrông virus in the Stoliczka's Asian trident bat (Aselliscus stoliczkanus) from Vietnam (Arai et al., 2019b); Láibīn virus in the black-bearded tomb bat (Taphozous melanopogon) from China (Xu et al., 2015) and Myanmar (Arai et al., 2019a); Huángpí virus in the Japanese house bat (Pipistrellus abramus) and Lóngquán virus in the Chinese horseshoe bat (Rhinolophus sinicus), Formosan lesser horseshoe bat (Rhinolophus monoceros) and intermediate horseshoe bat (Rhinolophus affinis) from China (Guo et al., 2013); Makokou virus in the Noack's roundleaf bat (Hipposideros ruber) from Gabon (Witkowski et al., 2016); Quezon virus in the Geoffroy's rousette (Rousettus amplexicaudatus) from the Philippines (Arai et al., 2016b); and Brno virus in the common noctule (Nyctalus noctula) from the Czech Republic (Straková et al., 2017).

Compared to the multitude of orthohantaviruses reported from more than half of the 50
Eulipotyphla species tested (Yanagihara et al., 2014), the cumulative number of newly recognized bat-borne hantaviruses is exceedingly low (Sumibcay et al., 2012; Weiss et al., 2012; Arai et al., 2013; Guo et al., 2013; Gu et al., 2014c; Xu et al., 2015; Arai et al., 2016b; Witkowski et al., 2016; Straková et al., 2017; Těšíková et al., 2017; Arai et al., 2019a; Arai et al., 2019b). The reasons for the low success rates of detecting hantavirus RNA in bat tissues are not altogether clear. One possibility is the highly divergent nature of their genomes, as well as the very focal or localized nature of hantavirus infection in bats and the small sample sizes of bat species, as well as primer mismatches, suboptimal PCR cycling conditions, and variable tissue preservation with degraded RNA (Arai et al., 2013; Gu et al., 2014c). Alternatively, bats may be less susceptible to hantavirus infection or may have developed immune mechanisms to curtail viral replication and/or persistence. In any case, as shown in Table 6.3, the full genomes of bat-borne hantaviruses are largely incomplete. Suboptimal primer design, imperfect cycling conditions, low RNA yields and poor RNA integrity (particularly in poorly preserved archival tissues collected under harsh field conditions) may have thwarted amplification and genome sequencing efforts (Gu et al., 2014c). However, while fewer bat species have been identified as reservoirs, the hantaviruses they harbour are among the most genetically diverse described to date.

\section{Hantaviruses in bats of the suborder Yangochiroptera}

The geographic distribution of four bat species belonging to the suborder Yangochiroptera, which harbour newfound orthohantaviruses, is shown in Fig. 6.1. A brief description of each hantavirus and its reservoir bat host is provided below and data are summarized in Table 6.2. Full genomes of Láibin virus and Brno virus are available (Table 6.3).

Mouyassué virus (MOYV) (genus Loanvirus). Detected in ethanol-fixed liver tissues from two of 12 banana pipistrelles captured near Mouyassué village ( $\mathrm{N} 05^{\circ} 22^{\prime} 07^{\prime}, \mathrm{W} 03^{\circ} 05^{\prime} 37^{\prime \prime}$ ) in Aboisso District, $130 \mathrm{~km}$ from Abidjan, in the extreme south-eastern region of Côte d'Ivoire during June 2011, MOYV was one of the first bat-borne hantaviruses reported (Sumibcay et al., 2012). The originally proposed three-letter abbreviation was changed to MOYV to avoid confusion with Moussa 


\begin{tabular}{|c|c|c|c|c|c|c|c|c|}
\hline \multirow[b]{2}{*}{ Suborder } & \multirow[b]{2}{*}{ Family } & \multirow[b]{2}{*}{ Genus and species } & \multirow[b]{2}{*}{ Country } & \multirow{2}{*}{$\begin{array}{l}\text { Year } \\
\text { trapped }\end{array}$} & \multirow[b]{2}{*}{ Virus Name } & \multicolumn{3}{|l|}{ Segment } \\
\hline & & & & & & $S$ & $M$ & $\mathrm{~L}$ \\
\hline \multirow[t]{7}{*}{ Yangochiroptera } & Emballonuridae & Taphozous melanopogon & China & 2012 & Láibīn & $\begin{array}{l}1935 \\
\text { KM102247 }\end{array}$ & $\begin{array}{l}3908 \\
\text { KM102248 }\end{array}$ & $\begin{array}{l}6531 \\
\text { KM102249 }\end{array}$ \\
\hline & & & Myanmar & 2015 & Láibīn & $\begin{array}{l}1776 \\
\text { MK064114 }\end{array}$ & $\begin{array}{l}3881 \\
\text { MK064115 }\end{array}$ & $\begin{array}{l}6531 \\
\text { MK064116 }\end{array}$ \\
\hline & Nycteridae & Nycteris hispida & Sierra Leone & 2010 & Magboi & & & $\begin{array}{l}414 \\
\text { JN037851 }\end{array}$ \\
\hline & Vespertilionidae & Neoromicia nanus & Côte d'Ivoire & 2011 & Mouyassué & & & $\begin{array}{l}1691 \\
\text { JQ287716 }\end{array}$ \\
\hline & & Neoromicia capensis & Ethiopia & 2014 & Mouyassué & & & $\begin{array}{l}237 \\
\text { KX184829 }\end{array}$ \\
\hline & & Pipistrellus abramus & China & 2011 & Huángpí & $\begin{array}{l}1115 \\
\text { JX473273 }\end{array}$ & & $\begin{array}{l}343 \\
\text { JX465369 }\end{array}$ \\
\hline & & Nyctalus noctula & $\begin{array}{l}\text { Czech } \\
\text { Republic }\end{array}$ & 2012 & Brno & $\begin{array}{l}1269 \\
\text { KX845678 }\end{array}$ & $\begin{array}{l}3408 \\
\text { KX845679 }\end{array}$ & $\begin{array}{l}6432 \\
\text { KX845680 }\end{array}$ \\
\hline \multirow[t]{8}{*}{ Yinpterochiroptera } & Hipposideridae & Hipposideros pomona & Vietnam & 2012 & Xuân Sơn & $\begin{array}{l}1748 \\
\text { KC688335 }\end{array}$ & $\begin{array}{l}3756 \\
\text { KU976427 }\end{array}$ & $\begin{array}{l}6520 \\
\text { JX912953 }\end{array}$ \\
\hline & & Hipposideros cineraceus & Vietnam & 2013 & Xuân Sơn & $\begin{array}{l}1660 \\
\text { MK393927 }\end{array}$ & $\begin{array}{l}1754 \\
\text { MK393928 }\end{array}$ & $\begin{array}{l}6521 \\
\text { LC406451 }\end{array}$ \\
\hline & & Hipposideros ruber & Gabon & 2012 & Makokou & & & $\begin{array}{l}3582 \\
\text { KT316176 }\end{array}$ \\
\hline & & Aselliscus stoliczkanus & Vietnam & 2013 & Đakrông & $\begin{array}{l}1746 \\
\text { MG663534 }\end{array}$ & $\begin{array}{l}3622 \\
\text { MG663535 }\end{array}$ & $\begin{array}{l}6535 \\
\text { MG663536 }\end{array}$ \\
\hline & Rhinolophidae & Rhinolophus sinicus & China & 2011 & Lóngquán & $\begin{array}{l}1564 \\
\text { JX465422 }\end{array}$ & $\begin{array}{l}3619 \\
\text { JX465402 }\end{array}$ & $\begin{array}{l}324 \\
\text { JX465388 }\end{array}$ \\
\hline & & Rhinolophus affinis & China & 2011 & Lóngquán & $\begin{array}{l}1545 \\
\text { JX465416 }\end{array}$ & $\begin{array}{l}3618 \\
\text { JX465398 }\end{array}$ & $\begin{array}{l}324 \\
\text { JX465382 }\end{array}$ \\
\hline & & Rhinolophus monoceros & China & 2011 & Lóngquán & $\begin{array}{l}1564 \\
\text { JX465419 }\end{array}$ & & $\begin{array}{l}324 \\
\text { JX465385 }\end{array}$ \\
\hline & Pteropodidae & Rousettus amplexicaudatus & Philippines & 2009 & Quezon & $\begin{array}{l}1830 \\
\text { KU950713 }\end{array}$ & $\begin{array}{l}3772 \\
\text { KU950714 }\end{array}$ & $\begin{array}{l}6556 \\
\text { KU950715 }\end{array}$ \\
\hline
\end{tabular}

The full-length genomes of one bat-borne loanvirus (Brno virus) and four bat-borne mobatviruses (Đakrông virus, Láibīn virus, Quezon virus and Xuân Sơn virus) have been sequenced. In addition, full-length S- and M-segment sequences are available for Lóngquán virus, a bat-borne loanvirus. The number of nucleotides for each segment sequenced to date, with GenBank number, is shown for each bat-borne loanvirus and mobatvirus.

Available Sequences

$$
\square \text { Full Length } \square>50 \%
$$$$
\square<50 \%
$$$$
\text { None }
$$ 


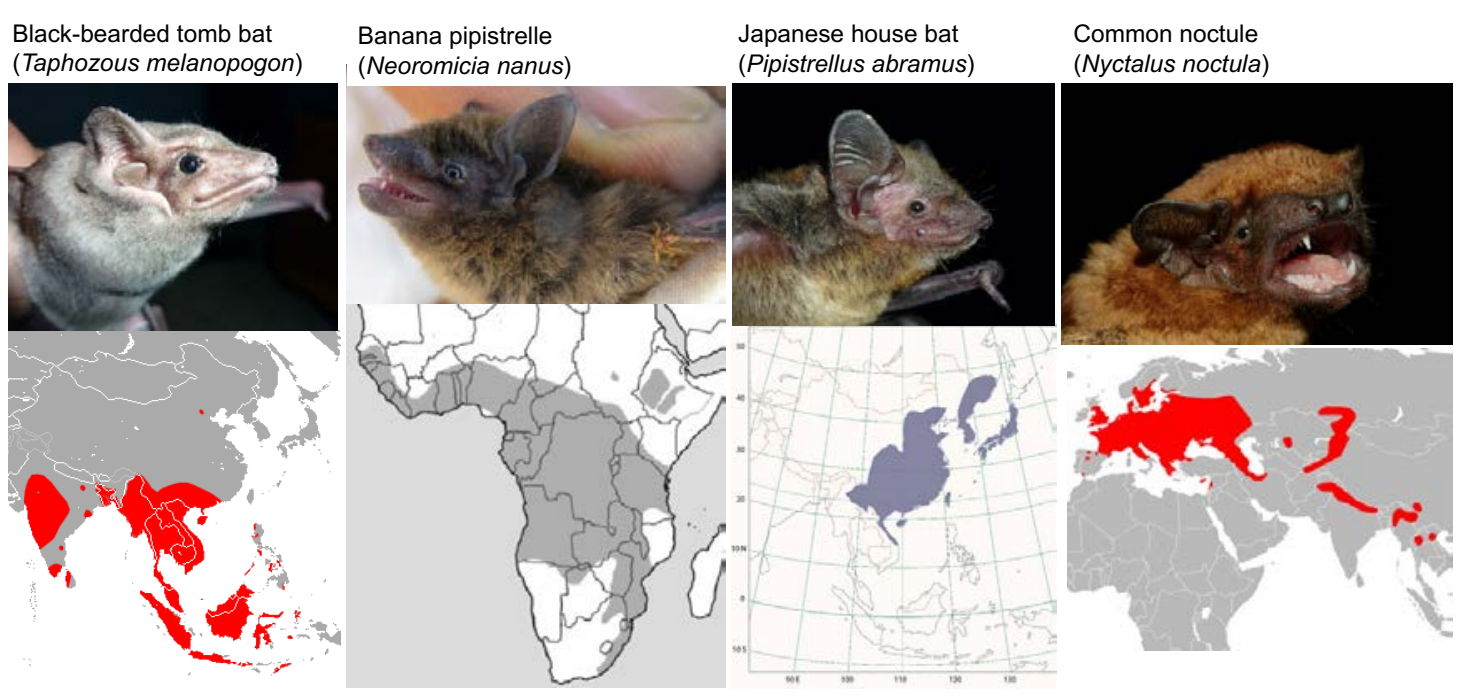

Figure 6.1 Geographic distribution of four bat species, belonging to the suborder Yangochiroptera, which harbour newfound loanviruses and mobatviruses. The black-bearded tomb bat (Taphozous melanopogon) (family Emballonuridae) hosts Láibīn virus; the banana pipistrelle (Neoromicia nanus) (family Vespertilionidae) hosts Mouyassué virus; the Japanese house bat (Pipistrellus abramus) (family Vespertilionidae) hosts Huángpi virus; and the common noctule (Nyctalus noctula) (family Vespertilionidae) hosts Brno virus. Not shown are the hairy slit-faced bat (Nycteris hispida) (family Nycteridae) and cape serotine (Neoromicia capensis) (family Vespertilionidae), which host Magboi virus and Mouyassué virus, respectively.

virus (MOUV), a newly described rhabdovirus isolated from Culex mosquitoes in Côte d'Ivoire (Quan et al., 2010). MOYV has also been found in one of nine cape serotines captured in Dhati Walel National Park (N 09¹3'33’, E 3452’37’), at an elevation of $1427 \mathrm{~m}$, in Ethiopia during February 2014 (Těšíková et al., 2017). The successful amplification of MOYV from ethanol-fixed tissues augments the potential pool of archival tissues for future exploratory studies of hantaviruses in bats, as well as other insectivorous small mammals that have shared ancestry with bats. The banana pipistrelle and cape serotine, which are distributed widely in forests and savannas across sub-Saharan Africa (Monadjem et al., 2017b, 2017c), are two of 13 species in the genus Neoromicia of the family Vespertilionidae. Like other vesper bats, the banana pipistrelle and cape serotine are insectivorous.

Magboi virus (MGBV) (genus Loanvirus). In analysing 525 tissue samples from 417 bats representing 28 genera for hantavirus RNA, a 414-nucleotide region of the $L$ segment of a newfound orthohantavirus, named MGBV, was detected in one of 18 hairy slit-faced bats captured at Magboi River within Gola National Park (N 0750.194', W $10^{\circ} 38.626^{\prime}$ ) in Sierra Leone during 2009 (Weiss et al., 2012). The host species (family Nycteridae) has a wide geographic range, encompassing much of sub-Saharan Africa, with the exception of the Horn of Africa and parts of southern Africa. There is an apparently disjunct population in western Mauritania close to the border with Senegal, and an isolated record from central Mali.

Huángpí virus (HUPV) (genus Loanvirus). Sequences from a 1115-nucleotide region of the $S$ segment and a 343-nucleotide region of the $\mathrm{L}$ segment are available for HUPV, which was detected in one of five Japanese house bats, captured in Huángpí District (N 3052’30”, E 114²2’30”), one of 13 districts of Wuhan, the capital of Húběi Province in China during 2012 (Guo et al., 2013). The Japanese house bat, a member of the family Vespertilionidae, is found in the southern Ussuri region (Russia and China), the western half of China including Taiwan, Japan, the Korean Peninsula, Vietnam, Myanmar, and India (Fig. 6.1) (Bates and Tsytsulina, 2008).

Láibin virus (LAIV) (genus Mobatvirus). The full-length genome (1935 nucleotide S, 3908 nucleotide $\mathrm{M}$ and 6531-nucleotide $\mathrm{L}$ segment) is available for LAIV strain BT20 (Table 6.3), which was originally detected in one of 32 black-bearded 
tomb bats, captured in Láibīn City (N 234ㄴ, E $109^{\circ} 14^{\prime}$ ) in Guăngxī Province in China during July 2012 (Xu et al., 2015). LAIV (strain BT33) has also been detected in one of 74 black-bearded tomb bats captured in May 2014 in Băisè, in Guăngxī Province, bordering Vietnam (Xu et al., 2019), as well as in two of 15 black-bearded tomb bats (strains MM4377M17 and MM4378M18), trapped in November 2015 in Shwe Ba Hill Cave in the Sagaing Region of Myanmar (Arai et al., 2019a). LAIV has the longest $M$ segment, which includes a 504-nucleotide long 3'-non-coding region. The black-bearded tomb bat is widely distributed throughout Asia and Southeast Asia (Fig. 6.1), including Brunei, Cambodia, China, India, Indonesia, Laos, Malaysia, Myanmar, Philippines, Singapore, Sri Lanka, Thailand, Timor-Leste and Vietnam (Csorba et al., 2008).

Brno virus (BRNV) (genus Loanvirus). In testing 53 bats, which had died accidentally or which were found dead, BRNV was detected in two of 12

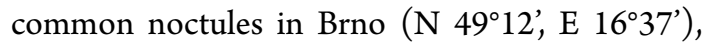
the second largest city in the Czech Republic (Straková et al., 2017). The entire genome of BRNV strain $7 / 2012$ is available (1269-nucleotide $S$, 3408-nucleotide $\mathrm{M}$ and 6432-nucleotide $\mathrm{L}$ ) (Table 6.3). To date, this is the only bat-borne hantavirus reported from Europe. Common noctules have a wide Palearctic distribution (Fig. 6.1), including Europe and southern Scandinavia to the Urals and Caucasus; Turkey to Israel and Oman; western Turkmenistan, western Kazakhstan, Uzbekistan, Kyrgyzstan, and Tajikistan to southwest Siberia and perhaps the Himalayas. Its occurrence in North Africa is questionable, and a record from Mozambique is considered dubious (Csorba and Hutson, 2016).

\section{Hantaviruses in bats of the suborder Yinpterochiroptera}

The geographic distribution of seven bat species belonging to the suborder Yinpterochiroptera, which harbour newfound orthohantaviruses is shown in Fig. 6.2. A brief description of each hantavirus and its reservoir bat host is provided below and data are summarized in Table 6.2. Full genomes of Xuân Sơn virus, Đakrông virus and Quezon virus are available.

Lóngquán virus (LQUV) (genus Loanvirus). LQUV was detected in six of 26 intermediate horseshoe bats (strains Ra-5, Ra-10, Ra-14, Ra-25, $\mathrm{Ra}-56$ and Ra-90), three of 135 Chinese rufous horseshoe bats (strains Rs-32, Rs-141 and Rs-168), and one of four Formosan lesser horseshoe bats (strain Rm-180), captured in Lóngquán City (N 28 $04^{\prime}, \mathrm{E} 119^{\circ} 08^{\prime}$ ) in southwestern Zhèjiāng Province in China during 2011 (Guo et al., 2013). Intermediate horseshoe bats are widespread throughout South Asia (Fig. 6.2), southern and central China and Southeast Asia (Walston et al., 2008); Chinese rufous horseshoe bats range from northern South Asia into northern Southeast Asia, and much of central, southern and southwestern China (Bates et al., 2008); and Formosan lesser horseshoe bats are reported as a Taiwanese species, but it is very similar to least horseshoe bats (Rhinolophus pusillus) in body size, echolocation call frequency and mitochondrial gene sequences. Least horseshoe bats have a very wide range from South Asia eastward to Japan, occurring also in southern and southwestern China, including Taiwan, southward through mainland Southeast Asia to Indonesia and Borneo (Hutson et al., 2008). Its ability to also host LQUV warrants study.

Xuân Sơn virus (XSV) (genus Mobatvirus). To date, six strains of XSV (VN1982B4, F42640, F42682, F44580, F44583 and F44601) have been detected in Pomona roundleaf bats, captured in Xuân Sơn National Park (N 21 ${ }^{\circ} 07^{\prime} 26.75^{\prime \prime}$, E 104'57'29.98”), a nature reserve in Thanh Sơn District, of Phú Thọ Province, approximately $100 \mathrm{~km}$ west of Hanoi, during July 2012; in $\mathrm{Na}$ Hang Nature Reserve (N 22 $2^{\circ}$, E 105 $15^{\prime}$ ) in Tuyên Quang Province during May 1997; and in Noc Ong Toan (N 15.1400', E 108.0200 $)$ in Quảng Nam Province during March 1999 (Arai et al., 2013; Gu et al., 2014c). XSV-infected Pomona roundleaf bats have also been captured in the Sagaing Region and in Nay Pyi Taw Union Territory of Myanmar (Arai et al., 2019a) and in Yúnnán Province of China (Xu et al., 2019). And in Vietnam, XSV has been detected in ashy roundleaf bats captured in Bắc Hướng Hóa Nature Reserve (N 1653'21”, E 106³4'14”) in Hướng Hóa District, Quảng Trị Province during August 2013; in Xuân Sơn National Park (N 2107’23”, E 104'57’36”) in Tân Sơn District, Phú Thọ Province during August 2015; and in Me Linh Station for Biodiversity (N 21.3927, $\left.\mathrm{E} 105.7145^{\circ}\right)$ in Phúc Yên District, Vĩnh Phúc Province during April 2016 (Arai et 


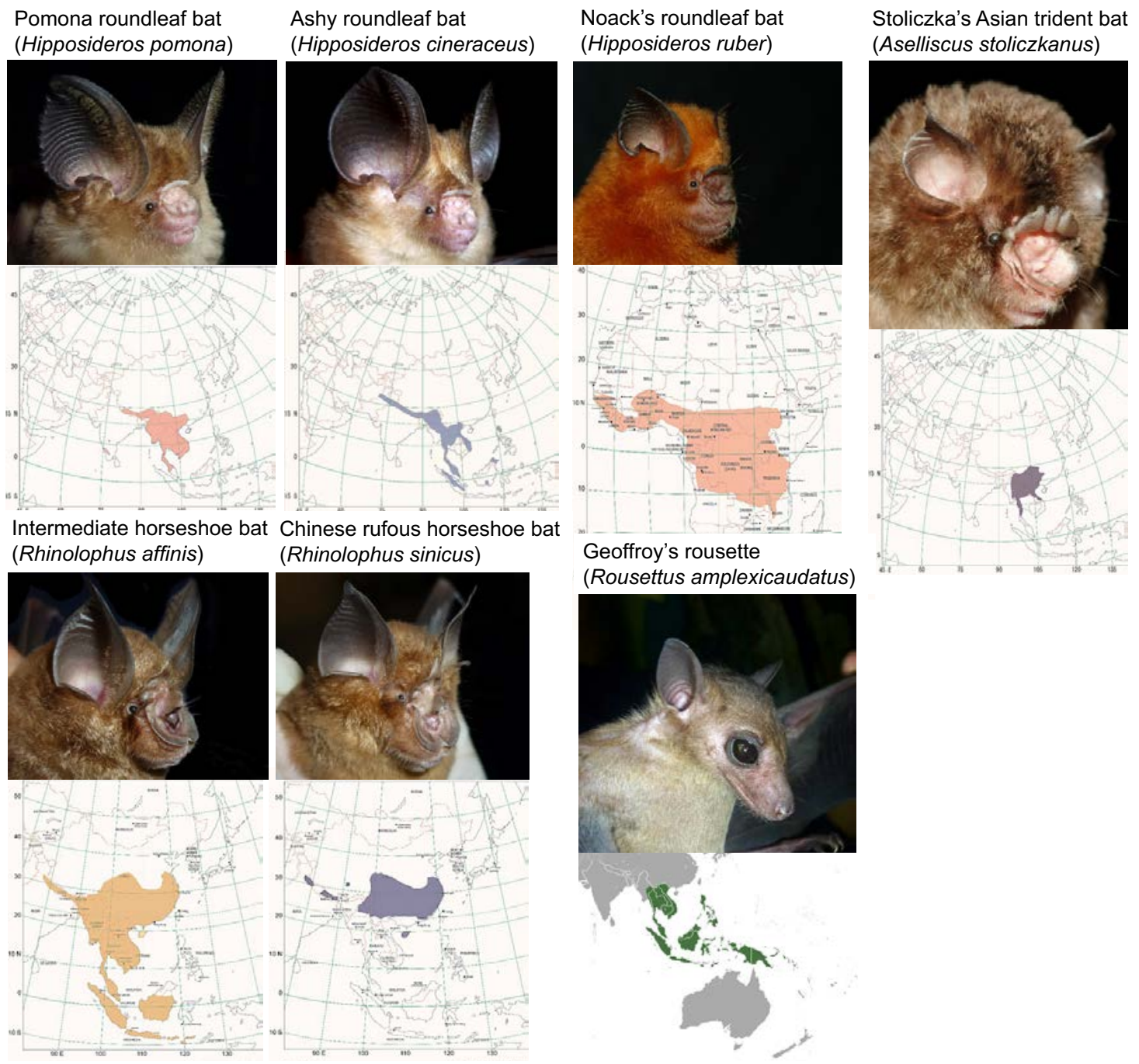

Figure 6.2 Geographic distribution of seven bat species, belonging to the suborder Yinpterochiroptera, which harbour newfound loanviruses and mobatviruses. The Pomona roundleaf bat (Hipposideros pomona) and ashy roundleaf bat (Hipposideros cineraceus) (family Hipposideridae) hosts Xuân Sơn virus; the Noack's roundleaf bat (Hipposideros ruber) (family Hipposideridae) hosts Makokou virus; the Stoliczka's Asian trident bat (Aselliscus stoliczkanus) (family Hipposideridae) hosts Đakrông virus; the intermediate horseshoe bat (Rhinolophus affinis) and Chinese rufous horseshoe bat (Rhinolophus sinicus) (family Rhinolophidae) hosts Lóngquán virus; and the Geoffroy's rousette (Rousettus amplexicaudatus) (family Pteropodidae) hosts Quezon virus.

al., 2019a). Recently, XSV strains have also been reported in ashy roundleaf bats from Guăngxī Province in China (Xu et al., 2019). Pomona roundleaf bats and ashy roundleaf bats are sympatric, but the latter species usually occurs in much lower abundance. Nevertheless, they often roost in the same caves, which may account for spillover of XSV.

The genome of prototype XSV strain VN1982B4 consists of 1748-nucleotide S, 3756-nucleotide $\mathrm{M}$ and 6520-nucleotide L (Table 6.3). The Hipposideros genus of the family Hipposideridae is one of the most speciose of insectivorous bats, with more than 70 species distributed across Africa, Europe, Asia and Australia. The vast geographic distribution of the Pomona roundleaf bat throughout Vietnam (Fig. 6.2), as well as in Bangladesh, Cambodia, China, India, Laos, Malaysia, Myanmar, Nepal and Thailand, provides opportunities to ascertain the genetic diversity 
and phylogeography of XSV and XSV-related hantaviruses. In this regard, although hantavirus RNA was not detected in archival tissues from several other Hipposideros species (H. cafer, $H$. cervinus, $H$. cyclops and H. gambianus) (Sumibcay et al., 2012; Weiss et al., 2012), it is very likely that many more genetically divergent mobatviruses are harboured by bat species in this large family.

Makokou virus (MAKV) (genus Mobatvirus). A partial 3582-nucleotide region of the $\mathrm{L}$ segment is available for MAKV, which was detected in one of 123 Noack's roundleaf bats, trapped in a cave near the city of Makokou ( $0^{\circ} 34^{\prime}, \mathrm{E} 12^{\circ} 52^{\prime}$ ) in Gabon during 2009 (Witkowski et al., 2016). A member of the family Hipposideridae, the Noack's roundleaf bat is one of the most common bat species in Africa (Fig. 6.2), ranging from west to east in central Africa, Angola, Benin, Burkina Faso, Burundi, Cameroon, Central African Republic, Chad, Republic of Congo, Democratic Republic of Congo, Côte d'Ivoire, Equatorial Guinea, Ethiopia, Gabon, Gambia, Ghana, Guinea, Guinea-Bissau, Kenya, Liberia, Malawi, Mali, Mozambique, Niger, Nigeria, Rwanda, São Tomé and Príncipe, Senegal, Sierra Leone, Sudan, Tanzania, Togo, Uganda and Zambia (Monadjem, 2017a).

Đakrông virus (DKGV) (genus Mobatvirus). The entire genome of DKGV strain VN2913B72 (1746-nucleotide S, 3622-nucleotide $\mathrm{M}$ and 6535-nucleotide L) (Table 6.3) has been detected in one of two Stoliczka's Asian trident bats, captured in Đakrông Nature Reserve (N 16³9'3”, E $\left.107^{\circ} 2^{\prime} 13^{\prime \prime}\right)$ in Quảng Trị Province in Vietnam in August 2013 (Arai et al., 2019b). The Stoliczka's Asian trident bat, one of three species in the genus Aselliscus, is found in northern Southeast Asia (Fig. 6.2), from Myanmar and southern China in the North through Thailand, Laos and Vietnam to Pulau Tioman Island, Peninsular Malaysia in the South. A closely related species, the Dong Bac's trident bat (Aselliscus dongbacana) (Tu et al., 2015), overlaps in body size, geographic distribution, echolocation and habitat, but orthohantavirus RNA could not be detected in this species (S. Arai et al., unpublished data).

Quezon virus (QZNV) (genus Mobatvirus). As the only hantavirus to date in a megabat, or flying fox species, QZNV, which was detected in one of 15 Geoffroy's rousettes, captured in Quezon National Park (N 1359', E 121 $\left.55^{\prime}\right)$, located approximately
$130 \mathrm{~km}$ southeast of Manila, on Luzon Island, in the Philippines during 2009 (Arai et al., 2016b), expands the host range of hantaviruses. The Geoffroy's rousette, one of 10 species in the genus Rousettus, is a megabat or Old World fruit bat typically roosting in caves and feeding on fruit, nectar and pollen throughout Southeast Asia and in the Malesia region of Oceania, in Myanmar, Thailand, Cambodia, Laos, Vietnam, Singapore, Indonesia, Borneo, East Timor, Solomon Islands, Bismarck Archipelago, Papua New Guinea and the Philippines (Fig. 6.2). Reproductive synchrony between Geoffroy's rousettes and two closely related species, long-tongued nectar bat (Macroglossus minimus) and lesser short-nosed fruit bat (Cynopterus brachyotis), has been documented in the Philippines (Heideman and Utzurrum, 2003).

\section{Molecular phylogeny}

Previously, the segregation of hantaviruses into clades that paralleled the molecular phylogeny of their rodent hosts suggested codivergence (Plyusnin et al., 1996). Recently, this concept has been challenged on the basis of the disjunction between the evolutionary rates of the host and virus species. Preferential host switching and local host-specific adaptation have been proposed to account for the largely congruent phylogenies (Ramsden et al., 2009). However, host-switching events alone do not completely explain the co-existence and distribution of genetically distinct hantaviruses among host species in three divergent taxonomic orders of small mammals spanning across four continents (Bennett et al., 2014).

Phylogenetic analyses, based on S-, M- and L-genomic sequences, using maximum-likelihood and Bayesian methods, indicate that all bat-borne hantaviruses (or loanviruses and mobatviruses) share a common ancestry (Fig. 6.3). In all analyses, Nova virus from the European mole segregates with the bat-associated mobatviruses. The basal position of bat- and mole-borne mobatviruses and selected shrew-borne hantaviruses (or thottimviruses), such as Thottapalayam virus in the Asian house shrew and Imjin virus in the Ussuri white-toothed shrew, suggests that bats, moles and/or shrews, rather than rodents, may have served as the primordial mammalian hosts of ancestral hantaviruses (Fig. 6.3). 

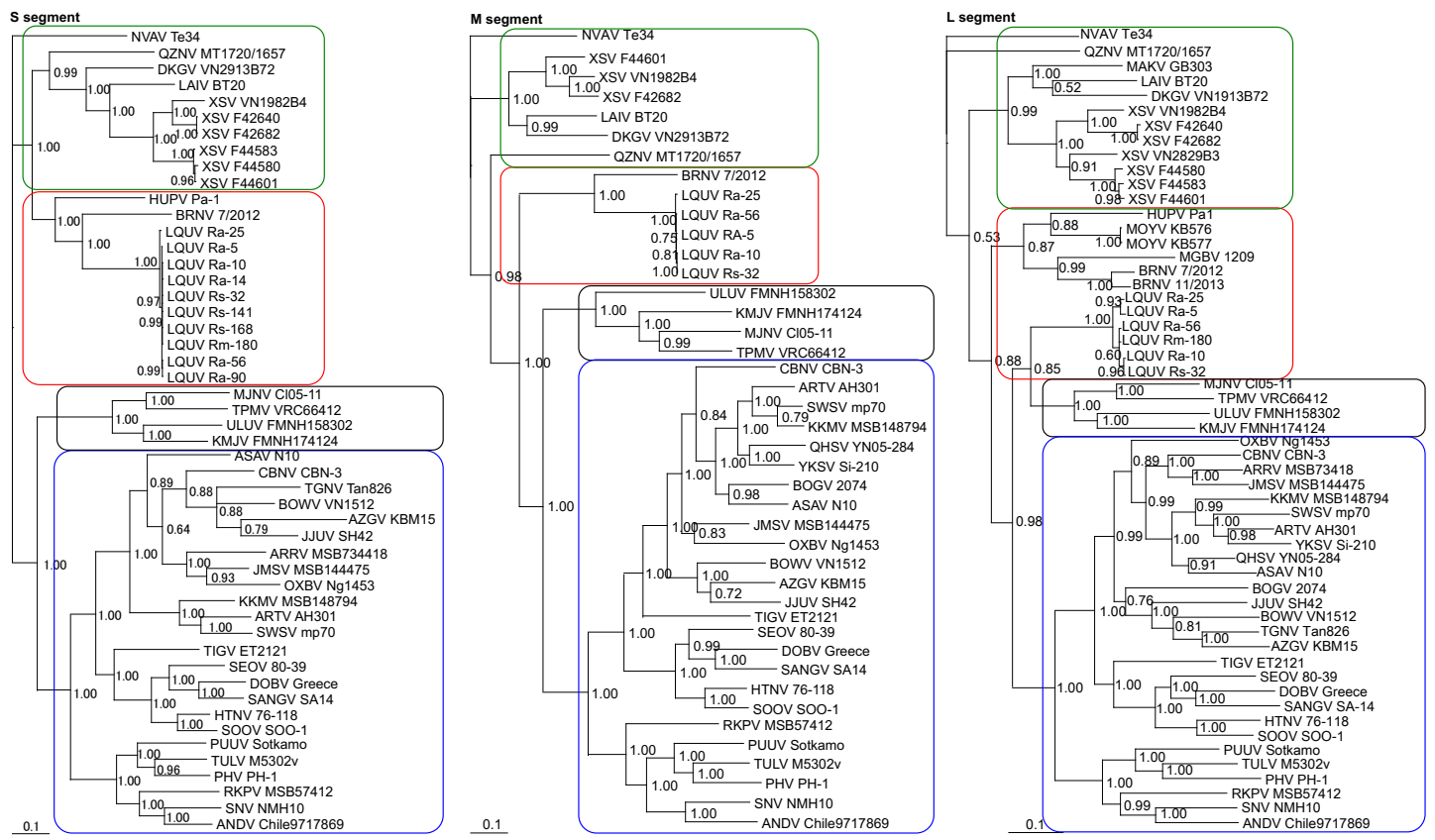

Figure 6.3 Phylogenetic trees, based sequences of the S-, M- and L-genomic segments, respectively, generated by the Bayesian Markov chain Monte Carlo estimation method, under the GTR $+\mathrm{I}+\Gamma$ model of evolution. The phylogenetic groupings of viruses belonging to the genera Loanvirus (red), Mobatvirus (green), Orthohantavirus (blue) and Thottimvirus (black) within the subfamily Mammantavirinae of the family Hantaviridae are shown. The numbers at each node are Bayesian posterior probabilities $(>0.7)$ based on 150,000 trees: two replicate Markov chain Monte Carlo runs, consisting of six chains of 10 million generations each sampled every 100 generations with a burn-in of $25,000(25 \%)$. Scale bars indicate nucleotide substitutions per site. Loanviruses include Brno virus (BRNV) strains 7/2012 (S: KX845678; M: KX845679; L: KX845680) and 11/2013 (L: KR920360), Lóngquán virus (LQUV) strains Ra-5 (S: JX465416; M: JX465398; L: JX465382), LQUV Ra-10 (S: JX465413; M: JX465396; L: JX465379), LQUV Ra-14 (S: JX465414), LQUV Ra-25 (S: JX465415; M: JX465397), LQUV Ra-56 (S: JX465417; M: JX465399; L: JX465383), LQUV Ra-90 (S: JX465418) from Rhinolophus affinis, LQUV Rs-32 (S: JX465422; M: JX465402; L: JX465388), LQUV Rs-141 (S: JX465420), LQUV Rs-168 (S: JX465421) from Rhinolophus sinicus, LQUV Rm-180 (S: JX465419; L: JX465385) from Rhinolophus monoceros, Magboi virus (MGBV) strain 1209 (L: JN037851) from Nycteris hispida, Mouyassué virus (MOYV) strains KB576 (L: JQ287716) and KB577 (L: KJ000540) from Neoromicia nanus, and Huángpí virus (HUPV) strain Pa-1 (S: JX473273; L: JX465369) from Pipistrellus abramus. Mobatviruses include Đakrông virus (DKGV) strain VN2913B72 (S: MG663536; M: MG663535; L: MG663534) from Aselliscus stoliczkanus, Láibīn virus (LAIV) strain BT20 (S: KM102247; M: KM102248; L: KM102249) from Taphozous melanopogon, Xuân Sơn virus (XSV) strains VN1982B4 (S: KC688335; M: KU976427; L: JX912953), F42640 (S: KF704708; L: KF704713), F42682 (S: KF704709; M: KJ000538; L: KF704714), F44580 (S: KF704710; L: KF704715), F44583 (S: KF704711; L: KF704716), F44601 (S: KF704712; M: KJ000539; L: KF704717) from Hipposideros pomona, XSV strain VN2829B3 (L: LC406451) from Hipposideros cineraceus, Makokou virus (MAKV) strain GB303 (L: KT316176) from Hipposideros ruber, Quezon virus (QZNV) strain MT1720/1657 (S: KU950713; M: KU950714; L: KU950715) from Rousettus amplexicaudatus, and Nova virus (NVAV) strain Te34 (S: KR072621; M: KR072622; L: KR072623) from Talpa europaea. Orthohantaviruses include Cao Bằng virus (CBNV) strain CBN-3 (S: EF543524; M: EF543526; L: EF543525) from Anourosorex squamipes, Ash River virus (ARRV) strain MSB734418 (S: EF650086; L: EF619961) from Sorex cinereus, Jemez Springs virus (JMSV) strain MSB144475 (S: FJ593499; M: FJ593500; L: FJ593501) from Sorex monticolus, Seewis virus (SWSV) strain mp70 (S: EF636024; M: EF636025; L: EF636026) from Sorex araneus, Artybash virus (ARTV) strain AH301 (S: KF974360; M: KF974359; L: KF974361) from Sorex caecutiens, Kenkeme virus (KKMV) strain MSB148794 (S: GQ306148; M: GQ306149; L: GQ306150) from Sorex roboratus, Qian Hu Shan virus (QHSV) strain YN05-284 (M: GU566022; L: GU566021) from Sorex cylindricauda, Yákèshí virus (YKSV) strain Si210 (M: NC_038705; L: JX465389) from Sorex isodon, and Boginia virus (BOGV) strain 2074 (L: JX990965) from Neomys fodiens, Azagny virus (AZGV) strain KBM15 (S: JF276226; M: JF276227; L: JF276228) from Crocidura obscurior, Tanganya virus (TGNV) strain Tan826 (S: EF050455; L: EF050454) from Crocidura theresea, Bowé virus (BOWV) strain VN1512 (S: KC631782; M: KC631783; L: KC631784) from Crocidura douceti, Jeju virus (JJUV) strain SH42 (S: HQ663933; M: HQ663934; L: HQ663935) from Crocidura shantungensis, Asama virus (ASAV) strain N10 (S: EU929072; M: EU929075; L: EU929078) from Urotrichus talpoides, Oxbow virus (OXBV) strain Ng1453 (S: FJ5339166; M: FJ539167; L: FJ593497) from Neurotrichus gibbsii, and Rockport virus (RKPV) strain MSB57412 (S: HM015223; M: HM015222; L: HM015221) from Scalopus aquaticus. Other orthohantavirus taxa include Sin Nombre virus (SNV) strain NMH10 (S: NC_005216; M: NC_005215; L: NC 005217), Andes virus (ANDV) strain Chile9717869 (S: AF291702; M: AF291703; L: AF291704), Prospect Hill virus (PHV) stain PH-1 (S: Z49098; M: X55129; L: EF646763), Tula virus (TULV) strain M5302v (S: NC_005227; M: NC_005228; L: NC_005226), Puumala virus (PUUV) strain Sotkamo (S: NC 005224; M: NC 005223; L: NC 005225), Dobrava virus (DOBV) strain Greece (S: NC 005233; M: NC_005234; L: NC_005235), Hantaan virus (HTNV) strain 76-118 (S: NC_005218; M: NC_005219; L: NC_005222), Soochong virus (SOOV) strain SOO-1 (S: AY675349; M: AY675353; L: DQ056292), Sangassou virus (SANGV) strain SA14 (S: JQ082300; M: JQ082301; L: JQ082302), Tigray virus (TIGV) strain ET2121 (S: KU934010; M: KU934009; L: KU934008), and Seoul virus (SEOV) strain 80-39 (S: NC 005236; M: NC 005237; L: NC 005238). Thottimiviruses include Thottapalayam virus (TPMV) strain VRC66412 (S: AY526097; M: NC_010708; L: EU001330) from Suncus murinus, Imjin virus (MJNV) strain Cl05-11 (S: EF641804; M: EF641798; L: EF641806) from Crocidura lasiura, Uluguru virus (ULUV) strain FMNH158302 (S: JX193695; M: JX193696; L: JX193697) from Myosorex geata, and Kilimanjaro virus (KMJV) strain FMNH174124 (S: JX193698; M: JX193699; L: JX193700) from Myosorex zinki. 
Geographic-specific clustering was evidenced by the close phylogenetic relationship between prototype XSV VN1982 from Phú Thọ Province and XSV F42640 and XSV F42682 from neighbouring Tuyên Quang Province in northern Vietnam. On the other hand, XSV F44583, XSV 44601 and XSV 44580 from Quảng Nam province in central Vietnam clustered together. Although limited differences are present in phylogenetic trees based on each segment, tree topologies are generally congruent and supported by significant bootstrap values $(>70 \%)$ and posterior node probabilities $(>0.70)$.

To compare the evolutionary relationships of loanviruses, mobatviruses, orthohantaviruses and thottimiviruses with their hosts, phylogenetic trees were reconstructed for co-phylogeny mapping, using consensus topologies based on amino acid sequences of the nucleocapsid protein, $\mathrm{Gn}$ and $\mathrm{Gc}$ glycoproteins and RNA-dependent RNA-polymerase. Such tanglegrams (Fig. 6.4), constructed using TreeMap 3b1243, exhibited congruent segregation of viruses within the family Hantaviridae, according to the subfamily of their reservoir hosts, with no evidence of host switching except for Asama virus, Oxbow virus, Nova virus and Rockport virus, which are all hantaviruses harboured by moles (Arai et al., 2008b; Kang et al., 2009b; Kang et al., 2011a). Asama virus and Oxbow virus were more closely aligned to soricine shrew-borne orthohantaviruses, Rockport virus shared a common ancestry with orthohantaviruses hosted by cricetid rodents and Nova virus was phylogenetically related to batborne mobatviruses (Figs. 6.3 and 6.4). Genetic recombination and reassortment events have also played a significant role in the evolution and the currently recognized diversity of the family Hantaviridae (Lee SH et al., 2017; Castel et al., 2017; Klempa, 2018).

Based on exhaustive phylogenetic analyses, using multiple methods, all bat-borne loanviruses and mobatviruses reported to date share a common ancestry, which is consistent with their host phylogeny. However, recently, in testing blood samples, obtained from 53 bats captured in south-eastern Brazil, for hantavirus infection, the partial S segment of an orthohantavirus, showing very high sequence similarity with Araraquara virus, was amplified from a Seba's short-tailed bat (Carollia perspicillata), a widespread frugivorous bat species in the family Phyllostomidae (Sabino-Santos et al., 2018). Also, partial S segment sequences of an Araraquara virus-like orthohantavirus was detected in the urine, heart, liver, lungs, spleen and kidneys of a common vampire bat (Desmodus rotundus), a sanguivorous phyllostomids species. Phylogenetic analysis showed that this Araraquara virus-like hantavirus formed a monophyletic group with Araraquara virus strain P5/Cajuru (GenBank EF571895), amplified from the blood of a HCPS patient in San Paulo (de Sousa et al., 2008) and strain IB_SP_bol66/2171 (EU170223), amplified from a hairy-tailed bolo mouse (Necromys lasiurus) captured in San Paulo, Brazil, in June 2005 (Ramsden et al., 2008). The detection of Araraquara virus-like orthohantavirus sequences in two phyllostomids species is decidedly unexpected. That a nearly identical sequence of an Araraquara virus-like orthohantavirus was amplified from two very different bat species in a laboratory known to work with Araraquara virus raises a high degree of suspicion that this surprising observation might represent laboratory contamination or PCR carryover.

That is, this observation is reminiscent of previously reported serological evidence of hantavirus infection in the common serotine (Eptesicus serotinus) and greater horseshoe bat (Rhinolophus ferrumequinum) captured in Korea (Kim et al., 1994). Subsequent genetic analysis of hantavirus isolates from these bat species proved to be indistinguishable from prototype Hantaan virus (Jung and Kim, 1995), indicating laboratory contamination. Nevertheless, intensified investigations by independent groups are warranted to confirm if bats serve as reservoir hosts of Araraquara viruslike orthohantaviruses. If they do, this would be somewhat akin to Rockport virus, harboured by the fossorial eastern mole, which shares a most recent common ancestor with cricetid rodent-borne orthohantaviruses. The eastern mole is sympatric and syntopic with cricetid rodent species, which serve as reservoir hosts of orthohantaviruses, suggesting a host-switching event in the distant past (Kang et al., 2011a).

\section{Discussion}

Because many emerging viral infectious diseases have their origins in mammalian reservoir hosts 


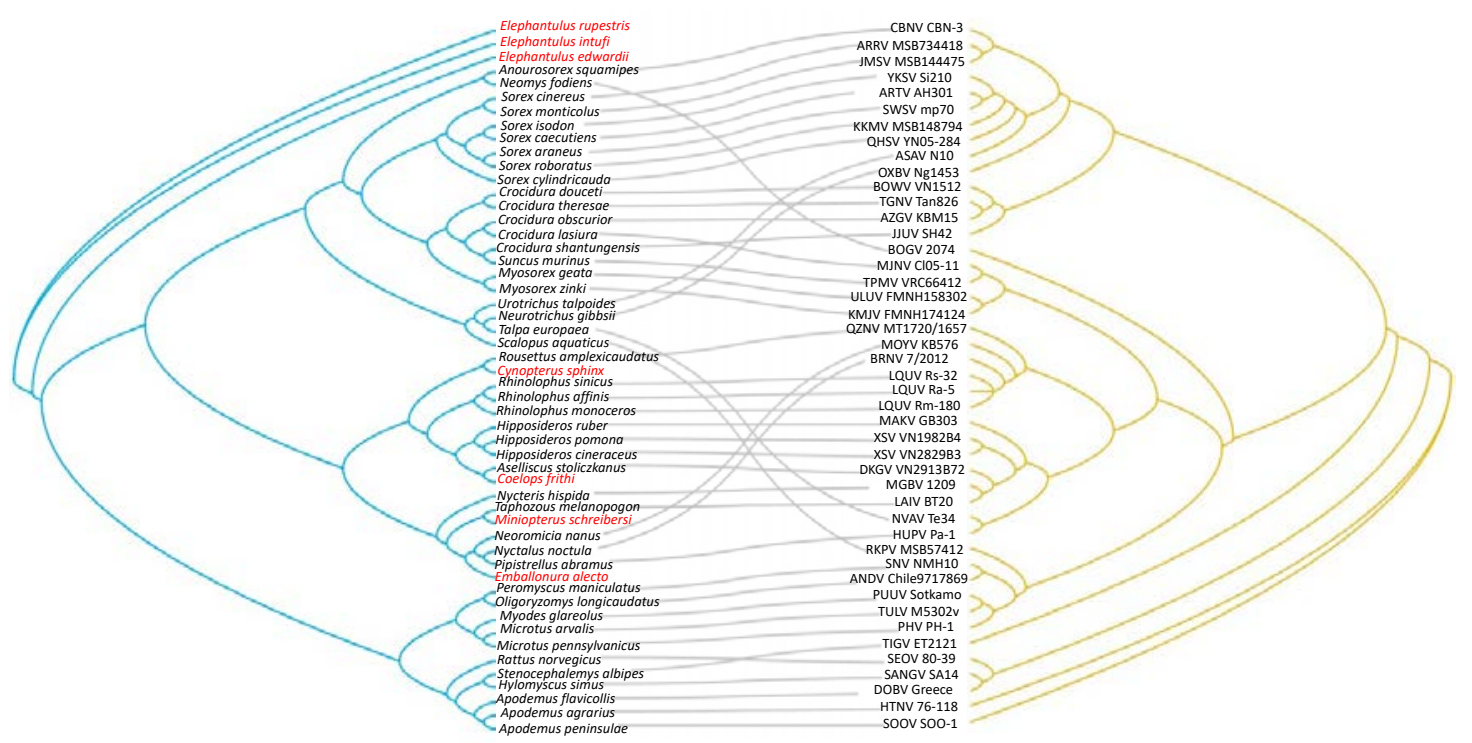

Figure 6.4 Tanglegram, generated by TreeMap 3b1243, comparing the phylogenies of orthohantaviruses and their Chiroptera, Eulipotyphla and Rodentia hosts. The host tree on the left was based on cytochrome $b$ gene sequences, while the hantavirus tree on the right was based on the amino acid sequences of the RNA-dependent RNA polymerase, generated by the Bayesian Markov chain Monte Carlo estimation method. The phylogenetic positions of each reservoir host and respective orthohantavirus are shown: Đakrông virus (DKGV) strain VN2913B72 (L: MG663534) from Aselliscus stoliczkanus (KU161570), Brno virus (BRNV) strain 7/2012 (L: KX845680) from Nyctalus noctula (JX570902), Magboi virus (MGBV) strain 1209 (L: JN037851) from Nycteris hispida (HQ693722), Mouyassué virus (MOYV) strain KB576 (L: JQ287716) from Neoromicia nanus (EU797428), Huángpí virus (HUPV) strain Pa-1 (L: JX465369) from Pipistrellus abramus (JX465352), Lóngquán virus (LQUV) strain Ra-5 (L: JX465381) from Rhinolophus affinis (JX465358), LQUV Rs-32 (L: JX465381) from Rhinolophus sinicus (JX465362), LQUV Rm-180 (L: JX465381) from Rhinolophus monoceros (JX465359), Láibīn virus (LAIV) strain BT20 (L: KM102249) from Taphozous melanopogon (LC406449), Makokou virus (MAKV) strain GB303 (L: KT316176) from Hipposideros ruber (EU934474), Xuân Sơn virus (XSV) strain VN1982B4 (L: JX912953) from Hipposideros pomona (JX912954) and XSV VN2829B3 (L: LC406451) from Hipposideros cineraceus (LC406452), and Quezon virus (QZNV) strain MT1720/1657 (L: KU950715) from Rousettus amplexicaudatus (KU950716) are shown in TreeMap dendrogram. Also shown are Cao Bằng virus (CBNV) strain CBN-3 (L: EF543525) from Anourosorex squamipes (AB175090), Ash River virus (ARRV) strain MSB734418 (L: EF619961) from Sorex cinereus (FJ667512), Jemez Springs virus (JMSV) strain MSB144475 (L: FJ593501) from Sorex monticolus (FJ667514), Seewis virus (SWSV) strain mp70 (L: EF636026) from Sorex araneus (FJ667524), Artybash virus (ARTV) strain AH301 (L: KF974361) from Sorex caecutiens (KF974362), Kenkeme virus (KKMV) strain MSB148794 (L: GQ306150) from Sorex roboratus (AB175128), Qian Hu Shan virus (QHSV) strain YN05-284 (L: GU566021) from Sorex cylindricauda (AB175121), Yákèshí virus (YKSV) strain Si-210 (L: JX465389) from Sorex isodon (JX465364), and Boginia virus (BOGV) strain 2074 (L: JX990965) from Neomys fodiens (KC537797), as well as Thottapalayam virus (TPMV) strain VRC66412 (L: EU001330) from Suncus murinus (DQ630386), Imjin virus (MJNV) strain CI05-11 (L: EF641806) from Crocidura lasiura (KJ004674), Azagny virus (AZGV) strain KBM15 (L: JF276228) from Crocidura obscurior (JF276229), Tanganya virus (TGNV) strain Tan826 (L: EF050454) from Crocidura theresea (DQ521043), Bowé virus (BOWV) strain VN1512 (L: KC631784) from Crocidura douceti (KC684929), Jeju virus (JJUV) strain SH42 (L: HQ663935) from Crocidura shantungensis (HQ663932), Uluguru virus (ULUV) strain FMNH158302 (L: JX193697) from Myosorex geata (JX193701), and Kilimanjaro virus (KMJV) strain FMNH174124 (L: JX193700) from Myosorex zinki (JX193702). Mole-borne orthohantaviruses include Asama virus (ASAV) strain N10 (L: EU929078) from Urotrichus talpoides (EU918371), Nova virus (NVAV) strain Te34 (L: KR072623) from Talpa europaea (FJ715340), Oxbow virus (OXBV) strain Ng1453 (L: FJ593497) from Neurotrichus gibbsii (FJ595237), and Rockport virus (RKPV) strain MSB57412 (L: HM015221) from Scalopus aquaticus (HM461914). Other taxa include Sin Nombre virus (SNV) strain NMH10 (L: NC 005217) from Peromyscus maniculatus (AF119261), Andes virus (ANDV) strain Chile9717869 (L: AF291704) from Oligoryzomys longicaudatus (AF346566), Prospect Hill virus (PHV) strain PH-1 (L: EF646763) from Microtus pennsylvanicus (AF119279), Tula virus (TULV) strain M5302v (L: NC 005226) from Microtus arvalis (AY220770), Puumala virus (PUUV) strain Sotkamo (L: NC_005225) from Myodes glareolus (JX477304), Dobrava virus (DOBV) strain Greece (L: NC_005235) from Apodemus flavicollis (JF819967), Hantaan virus (HTNV) strain 76-118 (L: NC_005222) form Apodemus agrarius (AB303225), Soochong virus (SOOV) strain SOO-1 (L: DQ056292) from Apodemus peninsulae (AB073811), Sangassou virus (SANGV) strain SA14 (L: JQ082302) from Hylomyscus simus (DQ212188), Tigray virus (TIGV) strain ET2121 (L: KU934008) from Stenocephalemys albipes (AF518346) and Seoul virus (SEOV) strain 80-39 (L: NC_005238) from Rattus norvegicus (AB355903). Outgroups include Elephantulus edwardii (DQ901019), Elephantulus intufi (DQ901206), Elephantulus rupestris (DQ901201) and no pair orthohantavirus host, Coelops frithii (DQ888674), Emballonura alecto (MK064108), Miniopterus schreibersii (MK064109) and Cynopterus sphinx (MK064110) are shown in red.

(Woolhouse and Gowtage-Sequeria, 2005), a better understanding about the geographic distribution of zoonotic viruses and their hosts is vital to assess risk and to predict future viral disease outbreaks, as well as to discover previously unrecognized disease associations in the case of still-orphan viruses harboured by small mammals (Han et al., 2016; Dunnum et al., 2017). While 
not all viruses in search of diseases, or orphan viruses, warrant investigations to ascertain their pathogenic potential and virulence at the time of their discovery, selected viruses, particularly those related to viruses known to cause severe and lifethreatening syndromes, such as HFRS and HCPS, are worthy of high research priority. No one would have predicted that rodent-borne orthohantaviruses could cause acute renal insufficiency with varying degrees of haemorrhage and shock, as well as a rapidly progressive, frequently fatal respiratory disease.

The realization that rodent-borne orthohantaviruses are capable of causing HFRS and HCPS raises the possibility that one or more newfound soricid- and talpid-associated orthohantaviruses or thottimviruses, and possibly bat-borne loanviruses and mobatviruses, may similarly cause a wide spectrum of febrile illnesses. In this regard, prospective studies of neotomine and sigmodontine rodent-borne orthohantaviruses in the early 1980s might have provided important clues about their pathogenicity and virulence long before the abrupt recognition of HCPS in 1993. In much the same way, one or more of the newly identified nonrodent-borne viruses of the family Hantaviridae may cause outbreaks of human disease and/or serve as surrogate antigens for the diagnosis of previously unrecognized diseases. Robust serological assays and other sensitive rapid diagnostic technologies, now under development, will assist in establishing if these newest members of the family Hantaviridae are pathogenic for humans. Also, studies on the genetics, transmission dynamics and disease-causing potential of one or more of the newly identified viruses in shrews, moles and bats, as well as African rodents, may better prepare the next generation of health care workers to be vigilant for the next outbreak of hantaviral disease.

That viruses of the subfamily Mammantavirinae are distributed widely across three taxonomic orders of terrestrial mammals has changed previously held dogmas about hantavirus evolution and phylogeography (Bennett et al., 2014). At the same time, although the global landscape of hantavirus distribution is far richer now than it was just a decade ago (Fig. 6.5), it is unclear if selection bias in the collection and availability, and subsequent testing of tissues from rodents, shrews, moles and bats, has distorted or unduly influenced our current concepts. For example, while rodents of multiple genera and species serve as reservoirs of orthohantaviruses, orthohantaviruses have been found in only two genera (Hylomyscus and Stenocephalemys) of rodents belonging to the subfamily Murinae in Africa, despite decades-long exploratory investigations. By contrast, in Eurasia, rodents belonging to genera in both the subfamilies Murinae (Apodemus, Bandicota, Niviventer and Rattus) and Arvicolinae (Arvicola, Eothenomys, Lemmus, Microtus, Myodes and Pitymys) are known to harbour orthohantaviruses. In the Americas, on the other hand, a dizzying diversity of orthohantaviruses has been found in rodent genera not only of the subfamilies Murinae (Rattus) and Arvicolinae (Microtus and Myodes), but also in the subfamilies Neotominae (Peromyscus and Reithrodontomys) and Sigmodontinae (Akodon, Calomys, Holochilus, Necromys, Oligoryzomys, Oryzomys, Sigmondon and Zygodontomys) (de Oliveira et al., 2014; Yanagihara et al., 2015). The caveat here is that rodents of the subfamilies Neotominae and Sigmodontinae do not exist in the Old World.

Multiple hantaviruses exhibiting far greater genetic diversity have been detected recently in shrews and moles representing genera in three subfamilies (Crocidurinae, Myosoricinae and Soricinae) of the family Soricidae and in two subfamilies (Talpinae and Scalopinae) of the family Talpidae, within the order Eulipotyphla, in Africa (Crocidura, Myosorex), Eurasia (Anourosorex, Neomys, Scaptonyx, Sorex, Suncus, Talpa and Urotrichus), and North America (Blarina, Neurotrichus, Scalopus and Sorex). Similarly, bat genera belonging to each of three families in both suborders of Chiroptera (Yinpterochiroptera and Yangochiroptera) host hantaviruses in Africa (Hipposideros, Neoromicia and Nycteris) and Eurasia (Aselliscus, Hipposideros, Nyctalus, Pipistrellus, Rhinolophus, Rousettus and Taphozous). To date, genetically distinct bat-borne hantaviruses have not been reported from the Americas.

Much work is obviously still needed to better understand the genetic diversity of viruses within the family Hantaviridae and the geographic distribution of their hosts. In particular, more intensive investigations are warranted to investigate beyond the more common families within the order Rodentia, as well as of the less well-known and low abundant genera within the order Eulipotyphla, 


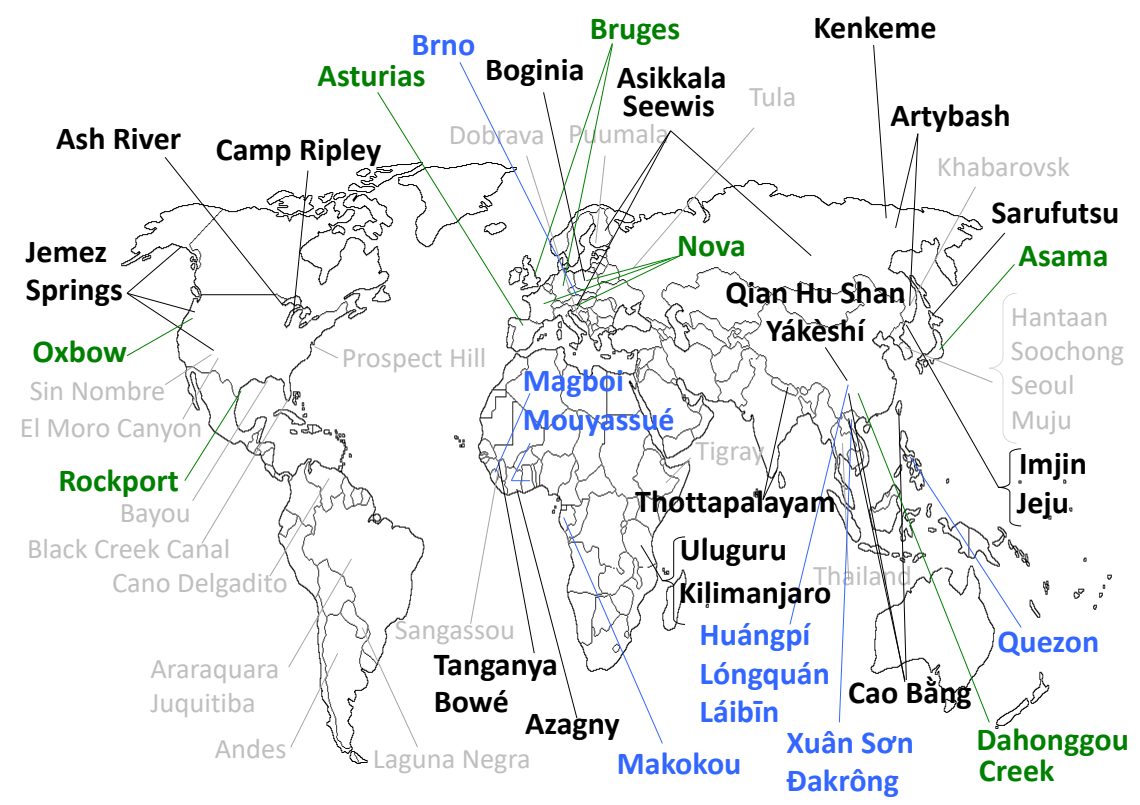

Figure 6.5 Global landscape of mammal-borne viruses within the family Hantaviridae. Representative hantaviruses harboured by rodents (grey) are shown, as are all hantaviruses detected to date in shrews (black), moles (green) and bats (blue).

and of the less speciose members of the suborders Yinpterochiroptera and Yangochiroptera.

Unlike the high prevalence of orthohantavirus infection reported in multiple species of shrews and moles, the absence of hantavirus infection in the majority of bat species analysed to date and the low prevalence of hantavirus RNA in only a few individuals of a given bat species would tend to argue against a long-standing hantavirus-bat host relationship, and instead support spillover or host-switching events. That is, the gleaning feeding behaviour of some bats, such as Nycteris, presents the possibility of acquired infection from excreta of well-established terrestrial reservoirs of orthohantaviruses. However, this seems highly improbable because bat-borne hantaviruses are among the most genetically diverse described to date and are phylogenetically distinct from hantaviruses harboured by rodents, shrews and moles.

With the discovery of divergent hantavirus lineages in three taxonomic orders of placental mammals, there is renewed interest in investigating their genetic diversity and geographic distribution. Newly acquired knowledge that bats harbour distinctly divergent lineages of hantaviruses emphasizes the truly complex evolutionary origins and phylogeography of a group of viruses once thought to be restricted to rodents. At this point, it would not be surprising if hantaviruses were found in small mammals belonging to other taxonomic orders, such as Erinaceomorpha (hedgehogs) and even Afrosoricida (tenrecs). Such discoveries may provide additional insights into the dynamics of hantavirus transmission, potential reassortment of genomes, and molecular determinants of hantavirus pathogenicity. As importantly, a sizable expansion of the Hantaviridae sequence database would provide valuable tools for refining diagnostic tests and enhancing preparedness for future outbreaks caused by still-orphan newfound hantaviruses.

\section{Future research}

Among the urgent questions for future research about the genetic diversity and geographic distribution of viruses within the family Hantaviridae are the following:

- What other taxonomic orders serve as reservoir hosts? That is, with the discovery of hantaviruslike sequences in reptile and fish, what is the host range of Hantaviridae? And do other terrestrial 
mammals, such as hedgehogs and tenrecs, harbour hantaviruses?

- What do the reservoir hosts have in common? Are some hosts more permissive to being recipients of host switches? Are some loanviruses, mobatviruses, orthohantaviruses and thottimiviruses more likely to switch into new hosts?

- What are the possibilities of developing more sensitive and less labour-intensive, primerindependent molecular detection tools for discovering other members of the family Hantaviridae?

- What is driving the evolutionary diversification of loanviruses, mobatviruses, orthohantaviruses and thottimiviruses? How do we definitively date divergence? What are the host evolutionary relationships?

Another unanswered question is whether or not one or more of the recently detected or yet-to-be discovered shrew- and mole-borne orthohantaviruses, or bat-borne loanviruses and mobatviruses, cause infection or disease in humans. In this regard, progress has been hampered by the lack of virus isolates from non-rodent hosts. That is, while multiple orthohantaviruses have been isolated from many rodent species and adapted to growth in cell culture or laboratory-bred rodents, there are, to date, only two thottimivirus isolates from shrews, namely, Thottapalayam virus from the Asian house shrew (Carey et al., 1971) and Imjin virus from the Ussuri white-tooted shrew (Song et al., 2009), and a single mole-borne mobatvirus isolate, namely, Nova virus from the European mole ( $\mathrm{Gu}$ et al., 2016b). There are no isolates of loanviruses or mobatviruses from bats. Future virus-isolation attempts may benefit from more innovative approaches, such as the use of reservoir host-derived cell cultures from tissues of shrews and bats (Eckerle et al., 2014).

Thus far, while there is suggestive evidence that Bowé virus and Uluguru virus (a shrew-borne orthohantavirus found in Guinea and a presumptive shrew-borne thottimivirus found in Tanzania, respectively) might cause infection in humans, as evidenced by serological tests using recombinant nucleocapsid proteins as antigens (Heinemann et al., 2016), there is no definitive proof that these or any of the newfound non-rodent-associated loanviruses, mobatviruses, orthohantaviruses and thottimiviruses cause a clinically identifiable disease or syndrome in humans (Yanagihara et al., 2015).

However, it would be premature to conclude that this would be true for other newfound and still-undiscovered soricid-, talpid- or Chiropteraborne viruses of the family Hantaviridae for the very reason that the majority of rodent-borne orthohantaviruses do not cause infection or disease in humans. A significant shortcoming of any investigation in search of a rare infectious disease event is the failure to study individuals who are affected by that rare event. On the one hand, the inability to detect antibodies against a given non-rodent-borne loanvirus, mobatvirus, orthohantavirus or thottimivirus in a given study population may indicate that that particular virus does not cause infection in humans. On the other hand, this same (negative) result could mean that the study simply failed to enrol subjects exposed to that virus. In other words, if infection with a given non-rodent-borne loanvirus, mobatvirus, orthohantavirus or thottimivirus is associated with a rare or uncommon disease, one would be unable to show pathogenicity in humans. In this regard, even at the height of the 1993 HCPS outbreak in the Four Corners region, no serological evidence of Sin Nombre virus infection could be found in patients with a variety of diseases or in health care workers, parks service personnel and mammalogists. Only patients with HCPS had evidence of Sin Nombre virus infection. Thus, even with the most lethal infectious agent, one would erroneously conclude that the microbe is non-pathogenic or non-infectious, unless the 'right' patients were tested.

Sensitive serological tests have facilitated the rapid screening of wild rodents for evidence of orthohantavirus infection. And in large part, this type of pre-screening has allowed more focused RT-PCR testing of antibody-positive rodents. By contrast, there are virtually no data about the prevalence of IgG antibodies against loanviruses, mobatviruses, orthohantaviruses and thottimiviruses in shrews, moles and bats, primarily because of the unavailability of blood or serum specimens in archival collections and the lack of suitable immunological reagents. However, as in rodents, one would surmise that antibody-positive shrews, moles and bats would more likely have detectable viral RNA. To what extent the presence of neutralizing antibodies against loanviruses or mobatviruses 
in bats would more readily pre-select which bats to test by RT-PCR is unknown. As it now stands, this is a moot point because no hantavirus isolates are available from bats to be able to perform neutralization tests.

For answers to these questions, and myriad others, reagents need to be developed. And multidisciplinary collaborative studies must be designed to optimize specimen collection to facilitate the isolation and characterization of newfound bat-borne loanviruses and mobatviruses to better understand virus-host interactions.

\section{Acknowledgements}

We thank Dr Nguyễn Trường Sơn and Dr Vương Tân Tú (of the Institute of Ecology and Biological Resources, Vietnam Academy of Science and Technology, in Hanoi, Vietnam), Dr Blaise Kadjo (of the Unité des biosciences, University 'Félix Houphouët-Boigny', in Abidjan, Côte d'Ivoire), and Dr Gábor Csorba (of the Hungarian Natural History Museum, in Budapest, Hungary) for providing the photos of bats. This work was supported in part by a grant-in-aid Research on Emerging and Re-emerging Infectious Diseases, Health Labour Sciences Research Grant in Japan (H25Shinko-Ippan-008), grants-in-aid on Research Program on Emerging and Re-emerging Infectious Diseases, Japan Agency for Medical Research and Development (AMED) (JP15fk0108005, JP16fk0108117, JP17fk0108217, JP18fk0108017 and JP19fk0108097), grant-in aid from the Japan Society for the Promotion of Science 24405045 (Scientific Research grant B), grant-in-aid on NAFOSTED (106-NN.05-2016.14), and VASTJSPS (QTJP01.02/18-20). Support was also provided by U.S. Public Health Service grant P30GM114737 from the National Institutes of Health.

\section{Note added in proof}

Since the submission of this manuscript, a new orthohantavirus, named Academ virus, has been detected in the Altai mole (Talpa altaica) from Western Siberia.

\section{References}

Adams, M.J., Lefkowitz, E.J., King, A.M.Q. Harrach, B., Harrison, R.L., Knowles, N.J., Kropinski, A.M., Krupovic, M., Kuhn, J.H., Mushegian, A.R., Nibert, M., Sabanadzovic, S., Sanfaçon, H., Siddell, S.G.,
Simmonds, P., Varsani, A., Zerbini, F.M., Gorbalenya, A.E., and Davison, A.J. (2017). Changes to taxonomy and the International Code of Virus Classification and Nomenclature ratified by the International Committee on Taxonomy of Viruses (2017). Arch. Virol. 162, 25052538. https://doi.org/10.1007/s00705-017-3358-5.

Arai, S., Song, J.-W., Sumibcay, L., Bennett, S.N., Nerurkar, V.R., Parmenter, C., Cook, J.A., Yates, T.L., and Yanagihara, R. (2007). Hantavirus in northern shorttailed shrew, United States. Emerg. Infect. Dis. 13, 1420-1423. https://doi.org/10.3201/eid1309.070484.

Arai, S., Bennett, S.N., Sumibcay, L., Cook, J.A., Song, J.-W., Hope, A., Parmenter, C., Nerurkar, V.R., Yates, T.L., and Yanagihara, R. (2008a). Phylogenetically distinct hantaviruses in the masked hrew (Sorex cinereus) and dusky shrew (Sorex monticolus) in the United States. Am. J. Trop. Med. Hyg. 78, 348-351.

Arai, S., Ohdachi, S.D., Asakawa, M., Kang, H.J., Mocz, G., Arikawa, J., Okabe, N., and Yanagihara, R. (2008b). Molecular phylogeny of a newfound hantavirus in the Japanese shrew mole (Urotrichus talpoides). Proc. Natl. Acad. Sci. USA. 105, 16296-16301. https://doi. org/10.1073/pnas.0808942105.

Arai, S., Gu, S.H., Baek, L.J., Tabara, K., Bennett, S.N., Oh, H.-S., Takada, N., Kang, H.J., Tanaka-Taya, K., Morikawa, S., Okabe, N., Yanagihara, R., and Song, J.-W. (2012). Divergent ancestral lineages of newfound hantaviruses harbored by phylogenetically related crocidurine shrew species in Korea. Virology 424, 99-105. https://doi. org/10.1016/j.virol.2011.11.013.

Arai, S., Nguyen, S.T., Boldgiv, B., Fukui, D., Araki, K., Dang, C.N., Ohdachi, S.D., Nguyen, N.X., Pham, T.D., Boldbaatar, B., Satoh, H., Yoshikawa, Y., Morikawa, S., Tanaka-Taya, K., Yanagihara, R., and Oishi, K. (2013). Novel bat-borne hantavirus, Vietnam. Emerg. Infect. Dis. 19, 1159-1161. https://doi.org/10.3201/ eid1907.121549.

Arai, S., Kang, H.J., Gu, S.H., Ohdachi, S.D., Cook, J.A., Yashina, L.N., Tanaka-Taya, K., Abramov, S.A., Morikawa, S., Okabe, N., Oishi, K., and Yanagihara, R. (2016a). Genetic diversity of Artybash virus in the Laxmann's shrew (Sorex caecutiens). Vector Borne Zoonotic Dis. 16, 468-475. https://doi.org/10.1089/ vbz.2015.1903.

Arai, S., Taniguchi, S., Aoki, K., Yoshikawa, Y., Kyuwa, S., Tanaka-Taya, K., Masangkay, J.S., Omatsu, T., Puentespina, R., Jr., Watanabe, S., Alviola, P., Alvarez, J., Eres, E., Cosico, E., Quibod, M.N., Morikawa, S., Yanagihara, R., and Oishi, K. (2016b). Molecular phylogeny of a genetically divergent hantavirus harbored by the Geoffroy's rousette (Rousettus amplexicaudatus), a frugivorous bat species in the Philippines. Infect. Genet. Evol. 45, 26-32. https://doi.org/10.1016/j. meegid.2016.08.008.

Arai, S., Kikuchi, F., Bawm, S., Nguyễn, T.S., Lin, K.S., Vương, T.T., Aoki, K., Tsuchiya, K., Tanaka-Taya, K., Morikawa, S., Oishi, K., and Yanagihara, R. (2019a). Molecular phylogeny of mobatviruses (Hantaviridae) in Myanmar and Vietnam. Viruses 11, 228. https://doi. org/10.3390/v11030228.

Arai, S., Aoki, K., Nguyễn, T.S., Vương, T.T., Kikuchi, F., Kinoshita, G., Fukui, D., Hoàng, T.T., Gu, S.H., Yoshikawa, Y., Tanaka-Taya, K., Morikawa, S., 
Yanagihara, R., and Oishi, K. (2019b). Đakrông virus, a novel mobatvirus (Hantaviridae) harbored by the Stoliczka's Asian trident bat (Aselliscus stoliczkanus) in Vietnam. Sci. Rep. 9, 10239.

Avšič-Županc, T., Xiao, S.Y., Stojanović, R., Gligić, A., van der Groen, G., and LeDuc, J.W. (1992). Characterization of Dobrava virus: a hantavirus from Slovenia, Yugoslavia. J. Med. Virol. 38, 132-137.

Avšič-Županc, T., Saksida, A., and Korva, M. (2016). Hantavirus infections. Clin. Microbiol. Infect. pii: $\quad$ S1198-743X(15)00536-4. https://doi. org/10.1111/1469-0691.12291.

Baek, L.J., Kariwa, H., Lokugamage, K., Yoshimatsu, K., Arikawa, J., Takashima, I., Kang, J.I., Moon, S.S., Chung, S.Y., Kim, E.J., Kang, H.J., Song, K.-J., Klein, T.A., Yanagihara, R., and Song, J.-W. (2006). Soochong virus: a genetically distinct hantavirus isolated from Apodemus peninsulae in Korea. J. Med. Virol. 78, 290-297. https:// doi.org/10.1002/jmv.20538.

Bates, P., Csorba, G., Molur, S., and Srinivasulu, C. (2008). Rhinolophus sinicus. In The IUCN Red List of Threatened Species 2008: e.T41529A10491334. https://doi.org/10.2305/IUCN.UK.2008.RLTS. T41529A10491334.en.

Bates, P., and Tsytsulina, K. (2008). Pipistrellus abramus. In The IUCN Red List of Threatened Species 2008: e.T17320A6972924. https://doi.org/10.2305/IUCN. UK.2008.RLTS.T17320A6972924.en.

Bennett, S.N., Gu, S.H., Kang, H.J., Arai, S., and Yanagihara, R. (2014). Reconstructing the evolutionary origins and phylogeography of hantaviruses. Trends Microbiol. 22, 473-482. https://doi.org/10.1016/j.tim.2014.04.008.

Blasdell, K., Cosson, J.F., Chaval, Y., Herbreteau, V., Douangboupha, B., Jittapalapong, S., Lundqvist, A., Hugot, J.P., Morand, S., and Buchy, P. (2011). Rodent-borne hantaviruses in Cambodia, Lao PDR, and Thailand. Ecohealth 8, 432-443. https://doi. org/10.1007/s10393-011-0725-7.

Brummer-Korvenkontio, M., Vaheri, A., Hovi, T., von Bonsdorff, C.H., Vuorimies, J., Manni, T., Penttinen, K., Oker-Blom, N., and Lähdevirta, J. (1980). Nephropathia epidemica: detection of antigen in bank voles and serologic diagnosis of human infection. J. Infect. Dis. 141, 131-134.

Carey, D.E., Reuben, R., Panicker, K.N., Shope, R.E., and Myers, R.M. (1971). Thottapalayam virus: a presumptive arbovirus isolated from a shrew in India. Indian J. Med. Res. 59, 1758-1760.

Castel, G., Tordo, N., and Plyusnin, A. (2017). Estimation of main diversification time-points of hantaviruses using phylogenetic analyses of complete genomes. Virus Res. 233, 60-69. https://doi.org/10.1016/j. virusres.2017.03.011.

Connolly-Andersen, A.M., Sundberg, E., Ahlm, C., Hultdin, J., Baudin, M., Larsson, J., Dunne, E., Kenny, D., Lindahl, T.L., Ramström, S., and Nilsson, S. (2015). Increased thrombopoiesis and platelet activation in hantavirusinfected patients. J. Infect. Dis. 212, 1061-1069. https:// doi.org/10.1093/infdis/jiv161.

Csorba, G., Bumrungsri, S., Helgen, K., Francis, C., Bates, P., Gumal, M., Balete, D., Heaney, L., Molur, S., and Srinivasulu, C. (2008). Taphozous melanopogon. In The IUCN Red List of Threatened Species 2008:
e.T21461A9281177. https://doi.org/10.2305/IUCN. UK.2008.RLTS.T21461A9281177.en.

Csorba, G., and Hutson, A.M. (2016). Nyctalus noctula. In The IUCN Red List of Threatened Species 2016: e.T14920A22015682. https://doi.org/10.2305/IUCN. UK.2016-2.RLTS.T14920A22015682.en.

de Oliveira, R.C., Guterres, A., Fernandes, J., D’Andrea, P.S., Bonvicino, C.R., and de Lemos, E.R. (2014). Hantavirus reservoirs: current status with an emphasis on data from Brazil. Viruses 6, 1929-1973. https://doi.org/10.3390/ v6051929.

de Sousa, R.L., Moreli, M.L., Borges, A.A., Campos, G.M., Livonesi, M.C., Figueiredo, L.T., and Pinto, A.A. (2008). Natural host relationships and genetic diversity of rodent-associated hantaviruses in southeastern Brazil. Intervirology 51, 299-310. https://doi. org/10.1159/000171818.

Deutz, A., Fuchs, K., Nowotny, N., Auer, H., Schuller, W., Stünzner, D., Aspock, H., Kerbl, U., and Köfer, J. (2003). Sero-epidemiological studies of zoonotic infections in hunters-comparative analysis with veterinarians, farmers, and abattoir workers. Wien Klin. Wochenschr. 115 Suppl 3, 61-67.

Duchin, J.S., Koster, F.T., Peters, C.J., Simpson, G.L., Tempest, B., Zaki, S.R., Ksiazek, T.G., Rollin, P.E., Nichol, S., Umland, E.T., Moolenaar, R.L., Reef, S.E., Nolte, K.B., Gallaher, M.M., Butler, J.,C., Breiman, R.F., and Hantavirus Study Group. (1994). Hantavirus pulmonary syndrome: a clinical description of 17 patients with a newly recognized disease. N. Engl. J. Med. 330, 949-955. https://doi.org/10.1056/ NEJM199404073301401.

Dunnum, J.L., Yanagihara, R., Johnson, K.M., Armien, B., Batsaikhan, N., Morgan, L., and Cook, J.A. (2017). Biospecimen repositories and integrated databases as critical infrastructure for pathogen discovery and pathobiology research. PLoS Negl. Trop. Dis. 11, e0005133. https://doi.org/10.1371/journal. pntd.0005133.

Eckerle, I., Lenk, M., and Ulrich, R.G. (2014). More novel hantaviruses and diversifying reservoir hosts--time for development of reservoir-derived cell culture models? Viruses 6, 951-967. https://doi.org/10.3390/ v6030951.

Elwell, M.R., Ward, G.S., Tingpalapong, M., and LeDuc, J.W. (1985). Serologic evidence of Hantaan-like virus in rodents and man in Thailand. Southeast Asian J. Trop. Med. Public Health 16, 349-354.

Fritz, C.L., Fulhorst, C.F., Enge, B., Winthrop, K.L., Glaser, C.A., and Vugia, D.J. (2002). Exposure to rodents and rodent-borne viruses among persons with elevated occupational risk. J. Occup. Environ. Med. 44, 962-967.

Fulhorst, C.F., Monroe, M.C., Salas, R.A., Duno, G., Utrera, A., Ksiazek, T.G., Nichol, S.T., de Manzione, N.M., Tovar, D., and Tesh, R.B. (1997). Isolation, characterization and geographic distribution of Caño Delgadito virus, a newly discovered South American hantavirus (family Bunyaviridae). Virus Res. 51, 159-171.

Fulhorst, C.F., Milazzo, M.L., Armstrong, L.R., Childs, J.E., Rollin, P.E., Khabbaz, R., Peters, C.J., and Ksiazek, T.G. (2007). Hantavirus and arenavirus antibodies in persons with occupational rodent exposure, North 
America. Emerg. Infect. Dis. 13, 532-538. https://doi. org/10.3201/eid1304.061509.

Gavrilovskaya, I.N., Apekina, N.S., Myasnikov, Yu.A., Bernshtein, A.D., Ryltseva, E.V., Gorbachkova, E.A., and Chumakov, M.P. (1983). Features of circulation of hemorrhagic fever with renal syndrome (HFRS) virus among small mammals in the European U.S.S.R. Arch. Virol. 75, 313-316.

Gligić, A., Stojanović, R., Obradović, M., Hlača, D., Dimković, N., Diglisić, G., Lukac, V., Ler, Z., Bogdanović, R., Antonijević, B., Ropac, D., Avšič, T., LeDuc, J.W., Ksiazek, T., Yanagihara, R., and Gajdusek, D.C. (1992). Hemorrhagic fever with renal syndrome in Yugoslavia: epidemiologic and epizootiologic features of a nationwide outbreak in 1989. Eur. J. Epidemiol. 8, $816-825$.

Goodin, D.G., Paige, R., Owen, R.D., Ghimire, K., Koch, D.E., Chu, Y.K., and Jonsson, C.B. (2009). Microhabitat characteristics of Akodon montensis, a reservoir for hantavirus, and hantaviral seroprevalence in an Atlantic forest site in eastern Paraguay.J. Vector Ecol.34, 104-113. https://doi.org/10.1111/j.1948-7134.2009.00013.x.

Gorbunova, E., Gavrilovskaya, I.N., and Mackow, E.R. (2010). Pathogenic hantaviruses Andes virus and Hantaan virus induce adherens junction disassembly by directing vascular endothelial cadherin internalization in human endothelial cells. J. Virol. 84, 7405-7411. https://doi.org/10.1128/JVI.00576-10.

Goüy de Bellocq, J., Těšíková, J., Meheretu, Y., Č́žzová, D., Bryjová, A., Leirs, H., and Bryja, J. (2016). Complete genome characterisation and phylogenetic position of Tigray hantavirus from the Ethiopian white-footed mouse, Stenocephalemys albipes. Infect. Genet. Evol. 45, 242-245. https://doi.org/10.1016/j. meegid.2016.09.009.

Groen, J., Gerding, M.N., Jordans, J.G., Clement, J.P., Nieuwenhuijs, J.H., and Osterhaus, A.D. (1995). Hantavirus infections in the Netherlands: epidemiology and disease. Epidemiol. Infect. 114, 373-383.

Grygorczuk, S., Pancewicz, S., Zajkowska, J., Kondrusik, M., Swierzbińska, R., Moniuszko, A., and Pawlak-Zalewska, W. (2008). Detection of anti-hantavirus antibodies in forest workers in the north-east of Poland. Przegl. Epidemiol. 62, 531-537.

Gu, S.H., Kang, H.J., Baek, L.J., Noh, J.Y., Kim, H.C., Klein, T.A., Yanagihara, R., and Song, J.-W. (2011). Genetic diversity of Imjin virus in the Ussuri whitetoothed shrew (Crocidura lasiura) in the Republic of Korea, 2004-2010. Virol. J. 8, 56. https://doi. org/10.1186/1743-422X-8-56.

Gu, S.H., Markowski, J., Kang, H.J., Hejduk, J., Sikorska, B., Liberski, P.P., and Yanagihara, R. (2013a). Boginia virus, a newfound hantavirus harbored by the Eurasian water shrew (Neomys fodiens) in Poland. Virol. J. 10, 160. https://doi.org/10.1186/1743-422X-10-160.

Gu, S.H., Nicolas, V., Lalis, A., Sathirapongsasuti, N., and Yanagihara, R. (2013b). Complete genome sequence and molecular phylogeny of a newfound hantavirus harbored by the Doucet's musk shrew (Crocidura douceti) in Guinea. Infect. Genet. Evol. 20, 118-123. https://doi.org/10.1016/j.meegid.2013.08.016.

$\mathrm{Gu}$, S.H., Dormion, J., Hugot, J.-P., and Yanagihara, R. (2014a) High prevalence of Nova hantavirus infection in the European mole (Talpa europaea) in France. Epidemiol. Infect. 142, 1167-1171. https://doi. org/10.1017/S0950268813002197.

Gu, S.H., Hejduk, J., Markowski, J., Kang, H.J., Markowski, M., Połatyńska, M., Sikorska, B., Liberski, P.P., and Yanagihara, R. (2014b). Co-circulation of soricid- and talpid-borne hantaviruses in Poland. Infect. Genet. Evol. 28, 296-303. https://doi.org/10.1016/j. meegid.2014.10.017.

Gu, S.H., Lim, B.K., Kadjo, B., Arai, S., Kim, J.A., Nicolas, V., Lalis, A., Denys, C., Cook, J.A., Dominguez, S.R., Holmes, K.V., Urushadze, L., Sidamonidze, K., Putkaradze, D., Kuzmin, I.V., Kosoy, M.Y., Song, J.-W., and Yanagihara, R. (2014c). Molecular phylogeny of hantaviruses harbored by insectivorous bats in Côte d'Ivoire and Vietnam. Viruses 6, 1897-1910. https:// doi.org/10.3390/v6051897.

Gu, S.H., Arai, S., Yu, H.-T., Lim, B.K., Kang, H.J., Song, J.-W., and Yanagihara, R. (2016a). Genetic variants of Cao Bang hantavirus in the Chinese mole shrew (Anourosorex squamipes) and Taiwanese mole shrew (Anourosorex yamashinai). Infect. Genet. Evol. 40, 113118. https://doi.org/10.1016/j.meegid.2016.01.031.

Gu, S.H., Kumar, M., Sikorska, B., Hejduk, J., Markowski, J., Markowski, M., Liberski, P.P., and Yanagihara, R. (2016b). Isolation and partial characterization of a highly divergent lineage of hantavirus from the European mole (Talpa europaea). Sci. Rep. 6, 21119. https://doi. org/10.1038/srep21119.

Gu, S.H., Miñarro, M., Forrester, N.L., Guerbois, M., Rojas, M., Fofanov, Y., Feliu, C., Hugot, J.-P., Weaver, S.C., and Yanagihara, R. (2016c). Newfound hantaviruses in the Iberian mole (Talpa occidentalis) in Spain [abstract no. 10105]. In Abstracts of the 64th annual meeting of the Japanese Society for Virology, Sapporo, Japan, October 23-25, 2016.

Guardado-Calvo, P., and Rey, F.A. (2017). The envelope proteins of the Bunyavirales. Adv. Virus Res. 98, 83-118. https://doi.org/10.1016/bs.aivir.2017.02.002.

Guo, W.P., Lin, X.D., Wang, W., Tian, J.H., Cong, M.L., Zhang, H.L., Wang, M.R., Zhou, R.H., Wang, J.B., Li, M.H., Xu, J., Holmes, E.C., and Zhang, Y.Z. (2013). Phylogeny and origins of hantaviruses harbored by bats, insectivores, and rodents. PLoS Pathog. 9, e1003159. https://doi.org/10.1371/journal.ppat.1003159.

Han, B.A., Kramer, A.M., and Drake, J.M. (2016). Global patterns of zoonotic disease in mammals. Trends Parasitol. 32, 565-577. https://doi.org/10.1016/j. pt.2016.04.007.

Heideman, P.D., and Utzurrum, R.C. (2003). Seasonality and synchrony of reproduction in three species of nectarivorous Philippines bats. BMC Ecol. 3, 11. https://doi.org/10.1186/1472-6785-3-11.

Heinemann, P., Tia, M., Alabi, A., Anon, J.C., Auste, B., Essbauer, S., Gnionsahe, A., Kigninlman, H., Klempa, B., Kraef, C., Krüger, N., Leendertz, F.H., Ndhatz-Sanogo, M., Schaumburg, F., Witkowski, P.T., Akoua-Koff, C.G., and Krüger, D.H. (2016). Human infections by non-rodent-associated hantaviruses in Africa. J. Infect. Dis. 214, 1507-1511. https://doi.org/10.1093/infdis/ jiw401.

Hjelle, B., Chavez-Giles, F., Torrez-Martinez, N., Yates, T., Sarisky, J., Webb, J., and Ascher, M. (1994). Genetic 
identification of a novel hantavirus of the harvest mouse Reithrodontomys megalotis. J. Virol. 68, 6751-6754.

Hutson, A.M., Kingston, T., and Walston, J. (2008). Rhinolophus pusillus. In The IUCN Red List of Threatened Species 2008: e.T19561A8977661. https://doi.org/10.2305/IUCN.UK.2008.RLTS. T19561A8977661.en.

Jiang, H., Du, H., Wang, L.M., Wang, P.Z., and Bai, X.F. (2016). Hemorrhagic fever with renal syndrome: pathogenesis and clinical picture. Front. Cell. Infect. Microbiol. 6, 1. https://doi.org/10.3389/ fcimb.2016.00001.

Jiang, H., Zheng, X., Wang, L., Du, H., Wang, P., and Bai, X. (2017). Hantavirus infection: a global zoonotic challenge. Virol. Sin. 32, 32-43. https://doi. org/10.1007/s12250-016-3899-x.

Johansson, P., Yap, G., Low, H.T., Siew, C.C., Kek, R., Ng, L.C., and Bucht, G. (2010). Molecular characterization of two hantavirus strains from different Rattus species in Singapore. Virol.J. 7, 15. https://doi.org/10.1186/1743422X-7-15.

Jonsson, C.B., Figueiredo, L.T.M., and Vapalahti, O. (2010). A global perspective on hantavirus ecology, epidemiology, and disease. Clin. Microbiol. Rev. 23, 412-441. https://doi.org/10.1128/CMR.00062-09.

Jung, Y.T., and Kim, G.R. (1995). Genomic characterization of $\mathrm{M}$ and S RNA segments of hantaviruses isolated from bats. Acta Virol. 39, 231-233.

Kang, H.J., Arai, S., Hope, A.G., Song, J.-W., Cook, J.A., and Yanagihara, R. (2009a). Genetic diversity and phylogeography of Seewis virus in the Eurasian common shrew in Finland and Hungary. Virol. J. 6, 208. https:// doi.org/10.1186/1743-422X-6-208.

Kang, H.J., Bennett, S.N., Dizney, L., Sumibcay, L., Arai, S., Ruedas, L.A., Song, J.-W., and Yanagihara, R. (2009b). Host switch during evolution of a genetically distinct hantavirus in the American shrew mole (Neurotrichus gibbsii). Virology 388, 8-14. https://doi.org/10.1016/j. virol.2009.03.019.

Kang, H.J., Bennett, S.N., Sumibcay, L., Arai, S., Hope, A.G., Mocz, G., Song, J.-W., Cook, J.A., and Yanagihara, R. (2009c). Evolutionary insights from a genetically divergent hantavirus harbored by the European common mole (Talpa europaea). PLOS ONE 4, e6149. https:// doi.org/10.1371/journal.pone.0006149.

Kang, H.J., Arai, S., Hope, A.G., Cook, J.A., and Yanagihara, R. (2010). Novel hantavirus in the flat-skulled shrew (Sorex roboratus). Vector Borne Zoonotic Dis. 10, 593-597. https://doi.org/10.1089/vbz.2009.0159.

Kang, H.J., Bennett, S.N., Hope, A.G., Cook, J.A., and Yanagihara, R. (2011a). Shared ancestry between a mole-borne hantavirus and hantaviruses harbored by cricetid rodents. J. Virol. 85, 7496-7503. https://doi. org/10.1128/JVI.02450-10.

Kang, H.J., Kadjo, B., Dubey, S., Jacquet, F., and Yanagihara, R. (2011b). Molecular evolution of Azagny virus, a newfound hantavirus in the West African pygmy shrew (Crocidura obscurior) in Côte d'Ivoire. Virol. J. 8, 373. https://doi.org/10.1186/1743-422X-8-373.

Kang, H.J., Kosoy, M.Y., Shrestha, S.K., Shrestha, M.P., Pavlin, J.A., Gibbons, R.V., and Yanagihara, R. (2011c). Genetic diversity of Thottapalayam virus, a hantavirus harbored by the Asian house shrew (Suncus murinus) in
Nepal. Am. J. Trop. Med. Hyg. 85, 540-545. https://doi. org/10.4269/ajtmh.2011.11-0034.

Kang, H.J., Stanley, W.T., Esselstyn, J.A., Gu, S.H., and Yanagihara, R. (2014). Expanded host diversity and geographic distribution of hantaviruses in subSaharan Africa. J. Virol. 88, 7663-7667. https://doi. org/10.1128/JVI.00285-14.

Kang, H.J., Gu, S.H., Cook, J.A., and Yanagihara, R. (2016). Dahonggou Creek virus, a divergent lineage of hantavirus harbored by the long-tailed mole (Scaptonyx fusicaudus). Trop. Med. Health 44, 16. https://doi. org/10.1186/s41182-016-0017-6.

Kariwa, H., Yoshizumi, S., Arikawa, J., Yoshimatsu, K., Takahashi, K., Takashima, I., and Hashimoto, N. (1995). Evidence for the existence of Puumula-related virus among Clethrionomys rufocanus in Hokkaido, Japan. Am. J. Trop. Med. Hyg. 53, 222-227.

Ketai, L.H., Williamson, M.R., Telepak, R.J., Levy, H., Koster, F.T., Nolte, K.B., and Allen, S.E. (1994). Hantavirus pulmonary syndrome: radiographic findings in 16 patients. Radiology 191, 665-668.

Kim, G.R., Lee, Y.T., and Park, C.H. (1994). A new natural reservoir of hantavirus: isolation of hantaviruses from lung tissues of bats. Arch. Virol. 134, 85-95.

Klempa, B., Fichet-Calvet, E., Lecompte, E., Auste, B., Aniskin, V., Meisel, H., Denys, C., Koivogui, L., ter Meulen, J., and Krüger, D.H. (2006). Hantavirus in African wood mouse, Guinea. Emerg. Infect. Dis. 12, 838-840. https://doi.org/10.3201/eid1205.051487.

Klempa, B., Fichet-Calvet, E., Lecompte, E., Auste, B., Aniskin, V., Meisel, H., Barriere, P., Koivogui, L., ter Meulen, J., and Krüger, D.H. (2007). Novel hantavirus sequences in shrew, Guinea. Emerg. Infect. Dis. 13, 520-522. https://doi.org/10.3201/eid1303.061198.

Klempa, B., Tkachenko, E.A., Dzagurova, T.K., Yunicheva, Y.V., Morozov, V.G., Okulova, N.M., Slyusareva, G.P., Smirnov, A., and Krüger, D.H. (2008). Hemorrhagic fever with renal syndrome caused by 2 lineages of Dobrava hantavirus, Russia. Emerg. Infect. Dis. 14, 617-625. https://doi.org/10.3201/eid1404.071310.

Klempa, B., Avšič-Županc, T., Clement, J., Dzagurova, T.K., Henttonen, H., Heyman, P., Jakab, F., Krüger, D.H., Maes, P., Papa, A., Tkachenko, E.A., Ulrich, R.G., Vapalahti, O., and Vaheri, A. (2013a). Complex evolution and epidemiology of Dobrava-Belgrade hantavirus: definition of genotypes and their characteristics. Arch. Virol. 158, 521-529. https://doi.org/10.1007/s0070012-1514-5.

Klempa, B., Radosa, L., and Krüger, D.H. (2013b). The broad spectrum of hantaviruses and their hosts in Central Europe. Acta Virol. 57, 130-137.

Klempa, B. (2018). Reassortment events in the evolution of hantaviruses. Virus Genes 54, 638-646. https://doi. org/10.1007/s11262-018-1590-z.

Korva, M., Knap, N., Rus, K.R., Fajs, L., Grubelnik, G., Bremec, M., Knapič, T., Trilar, T., and Županc, T.A. (2013). Phylogeographic diversity of pathogenic and non-pathogenic hantaviruses in Slovenia. Viruses 5, 3071-3087. https://doi.org/10.3390/v5123071.

Lähdevirta, J. (1971). Nephropathia epidemica in Finland. A clinical histological and epidemiological study. Ann. Clin. Res. 3, 1-54. 
Laenen, L., Vergote, V., Kafetzopoulou, L.E., Bokalinga, T.W., Vassou, D., Cook, J.A., Hugot, J.P., Deboutte, W., Kang, H.J., Witkowski, P.T., Köppen-Rung, P., Krüger, D.H., Ličková, M., Stang, A., Striešková, L., Szemeš, T., Markowski, J., Hejduk, J., Kafetzopoulos, D., Van Ranst, M., Yanagihara, R., Klempa, B., and Maes, P. (2018). A novel hantavirus of the European mole, Bruges virus, is involved in frequent Nova virus co-infections. Genome Biol. Evol. 10, 45-55. https://doi.org/10.1093/gbe/ evx268.

Lee, H.W., Lee, P.-W., and Johnson, K.M. (1978). Isolation of the etiologic agent of Korean hemorrhagic fever. J. Infect. Dis. 137, 298-308.

Lee, H.W., Lee, P.-W., Lähdevirta, J., and BrummerKorventkontio, M. (1979). Aetiological relation between Korean haemorrhagic fever and nephropathia epidemica. Lancet 1, 186-187.

Lee, H.W., Baek, L.J., and Johnson, K.M. (1982). Isolation of Hantaan virus, the etiologic agent of Korean hemorrhagic fever, from wild urban rats. J. Infect. Dis. 146, 638-644.

Lee, J.G., Gu, S.H., Baek, L.J., Shin, O.S., Park, K.S., Kim, H.-C., Klein, T.A., Yanagihara, R., and Song, J.-W. (2014). Muju virus, harbored by Myodes regulus in Korea, might represent a genetic variant of Puumala virus, the prototype arvicolid rodent-borne hantavirus. Viruses 6, 1701-1714. https://doi.org/10.3390/v6041701.

Lee, P.-W., Amyx, H.L., Gajdusek, D.C., Yanagihara, R.T., Goldgaber, D., and Gibbs, C.J., Jr. (1982). New haemorrhagic fever with renal syndrome-related virus in indigenous wild rodents in United States. Lancet 2, 1405 .

Lee, P.-W., Amyx, H.L., Yanagihara, R., Gajdusek, D.C., Goldgaber, D., and Gibbs, C.J., Jr. (1985). Partial characterization of Prospect Hill virus isolated from meadow voles in the United States. J. Infect. Dis. 152, 826-829.

Lee, S.H., Kim, W.K., No, J.S., Kim, J.A., Kim, J.I., Gu, S.H., Kim, H.C., Klein, T.A., Park, M.S., and Song, J.-W. (2017). Dynamic circulation and genetic exchange of a shrew-borne hantavirus, Imjin virus, in the Republic of Korea. Sci. Rep. 7, 44369. https://doi.org/10.1038/ srep44369.

Levis, S., Morzunov, S.P., Rowe, J.E., Enria, D., Pini, N., Calderon, G., Sabattini, M., and St. Jeor, S.C. (1998). Genetic diversity and epidemiology of hantaviruses in Argentina. J. Infect. Dis. 177, 529-538.

Levis, S., Garcia, J., Pini, N., Calderón, G., Ramírez, J., Bravo, D., St, Jeor, S., Ripoll, C., Bego, M., Lozano, E., Barquez, R., Ksiazek, T.G., and Enria, D. (2004). Hantavirus pulmonary syndrome in northwestern Argentina: circulation of Laguna Negra virus associated with Calomys callosus. Am. J. Trop. Med. Hyg. 71, 658-663.

Ling, J., Sironen, T., Voutilainen, L., Hepojoki, S., Niemimaa, J., Isoviita, V.M., Vaheri, A., Henttonen, H., and Vapalahti, O. (2014). Hantaviruses in Finnish soricomorphs: evidence for two distinct hantaviruses carried by Sorex araneus suggesting ancient hostswitch. Infect. Genet. Evol. 27, 51-61. https://doi. org/10.1016/j.meegid.2014.06.023.

Llah, S.T., Mir, S., Sharif, S., Khan, S., and Mir, M.A. (2018). Hantavirus-induced cardiopulmonary syndrome: a public health concern. J. Med. Virol. 90, 1003-1009. https://doi.org/10.1002/jmv.25054.

Lundkvist, A., Vapalahti, O., Henttonen, H., Vaheri, A., and Plyusnin, A. (2000). Hantavirus infections among mammalogists studied by focus reduction neutralisation test. Eur. J. Clin. Microbiol. Infect. Dis. 19, 802-803.

MacNeil, A., Ksiazek, T.G., and Rollin, P.E. (2011). Hantavirus pulmonary syndrome, United States, 1993-2009. Emerg. Infect. Dis. 17, 1195-1201. https:// doi.org/10.3201/eid1707.101306.

Maes, P., Alkhovsky, S.V., Bào, Y., Beer, M., Birkhead, M., Briese, T., Buchmeier, M.J., Calisher, C.H., Charrel, R.N., Choi, I.R., Clegg, C.S., de la Torre, J.C., Delwart, E., DeRisi, J.L., Di Bello, P.L., Di Serio, F., Digiaro, M., Dolja, V.V., Drosten, C., Druciarek, T.Z., Du, J., Ebihara, H., Elbeaino, T., Gergerich, R.C., Gillis, A.N., Gonzalez, J.J., Haenni, A.L., Hepojoki, J., Hetzel, U., Hồ, T., Hóng, N., Jain, R.K., Jansen van Vuren, P., Jin, Q. Jonson, M.G., Junglen, S., Keller, K.E., Kemp, A., Kipar, A., Kondov, N.O., Koonin, E.V., Kormelink, R., Korzyukov, Y., Krupovic, M., Lambert, A.J., Laney, A.G., LeBreton, M., Lukashevich, I.S., Marklewitz, M., Markotter, W., Martelli, G.P., Martin, R.R., MielkeEhret, N., Mühlbach, H.P., Navarro, B., Ng, T.F.F., Nunes, M.R.T., Palacios, G., Pawęskam, J.T., Peters, C.J., Plyusnin, A., Radoshitzky, S.R., Romanowski, V., Salmenperä, P., Salvato, M.S., Sanfaçon, H., Sasaya, T., Schmaljohn, C., Schneider, B.S., Shirako, Y., Siddell, S., Sironen, T.A., Stenglein, M.D., Storm, N., Sudini, H., Tesh, R.B., Tzanetakis, I.E., Uppala, M., Vapalahti, O., Vasilakis, N., Walker, P.J., Wáng, G., Wáng, L., Wáng, Y., Wèi, T., Wiley, M.R., Wolf, Y.I., Wolfe, N.D., Wú, Z., Xú, W., Yang, L., Yāng, Z., Yeh, S.D., Zhāng, Y.Z., Zhèng, Y., Zhou, X., Zhū, C., Zirkel, F., and Kuhn, J.H. (2018). Taxonomy of the family Arenaviridae and the order Bunyavirales: update 2018. Arch. Virol. 163, 2295-2310. https://doi.org/10.1007/s00705-018-3843-5.

Maes, P., Adkins, S., Alkhovsky, S.V., Avšič-Županc, T., Ballinger, M.J., Bente, D.A., Beer, M., Bergeron, E., Blair, C.D., Briese, T., Buchmeier, M.J., Burt, F.J., Calisher, C.H., Charbonnel, N., Charrel, R.N., Choi, I.R., Clegg, J.C.S., de la Torre, J.C., de Lamballerie, X., DeRisi, J.L., Digiaro, M., Drebot, M., Ebihara, H., Elbeaino, T., Ergünay, K., Fulhorst, C.F., Garrison, A.R., Gāo, G.F., Gonzalez, J.-P.J., Groschup, M.H., Günther, S., Haenni, A.-L., Hall, R.A., Hewson, R., Hughes, H.R., Jain, R.K., Jonson, M.G., Junglen, S., Klempa, B., Klingström, J., Kormelink, R., Lambert, A.J., Langevin, S.A., Lukashevich, I.S., Marklewitz, M., Martelli, G.P., Mielke-Ehret, N., Mirazimi, A., Mühlbach, H.-P., Naidu, R., Teixeira Nunes, M.R., Palacios, G., Papa, A., Pawęska, J.T., Peters, C.J., Plyusnin, A., Radoshitzky, S.R., Resende, R.O., Romanowski, V., Sall, A.A., Salvato, M.S., Sasaya, T., Schmaljohn, C., Shí, X., Shirako, Y., Simmonds, P., Sironi, M., Song, J.-W., Spengler, J.R., Stenglein, M.D., Tesh, R.B., Turina, M., Wèi, T., Whitfield, A.E., Yeh, S.-D., Murilo Zerbini, F.M., Zhāng, Y.-Z., Zhou, X., and Kuhn, J.H. (2019). Taxonomy of the order Bunyavirales: second update 2018. Arch. Virol. https://doi.org/10.1007/s00705-018-04126-4.

Martinez, V.P., Bellomo, C., San Juan, J., Pinna, D., Forlenza, R., Elder, M., and Padula, P.J. (2005). Person-to-person 
transmission of Andes virus. Emerg. Infect. Dis. 11, 1848-1853. https://doi.org/10.3201/eid1112.050501.

Martinez, V.P., Bellomo, C.M., Cacace, M.L., Suarez, P., Bogni, L., and Padula, P.J. (2010). Hantavirus pulmonary syndrome in Argentina, 1995-2008. Emerg. Infect. Dis. 16, 1853-1860. https://doi.org/10.3201/ eid1612.091170.

Martinez-Valdebenito, C., Calvo, M., Vial, C., Mansilla, R., Marco, C., Palma, R.E., Vial, P.A., Valdivieso, F., Mertz, G., and Ferrés, M. (2014). Person-to-person household and nosocomial transmission of andes hantavirus, Southern Chile, 2011. Emerg. Infect. Dis. 20, 16291636. https://doi.org/10.3201/eid2010.140353.

Mertens, M., Hofmann, J., Petraityte-Burneikiene, R., Ziller, M., Sasnauskas, K., Friedrich, R., Niederstrasser, O., Krüger, D.H., Groschup, M.H., Petri, E., Werdermann, S., and Ulrich, R.G. (2011). Seroprevalence study in forestry workers of a non-endemic region in eastern Germany reveals infections by Tula and DobravaBelgrade hantaviruses. Med. Microbiol. Immunol. 200, 263-268. https://doi.org/10.1007/s00430-0110203-4.

Mertz, G.J., Hjelle, B., Crowley, M., Iwamoto, G., Tomicic, V., and Vial, P.A. (2006). Diagnosis and treatment of New World hantavirus infections. Curr. Opin. Infect. Dis. 19, 437-442. https://doi.org/10.1097/01. qco.0000244048.38758.1f.

Monadjem, A., Fahr, J., Hutson, A.M., Mickleburgh, S., and Bergmans, W. (2017a). Hipposideros ruber. In The IUCN Red List of Threatened Species 2017: e.T10157A22102440. https://doi.org/10.2305/IUCN. UK.2017-2.RLTS.T10157A22102440.en.

Monadjem, A., Jacobs, D., Racey, P.A., Hutson, A.M., and Goodman, S. (2017b). Neoromicia nana. In The IUCN Red List of Threatened Species 2017: e.T44923A22047621. https://doi.org/10.2305/IUCN. UK.2017-2.RLTS.T44923A22047621.en.

Monadjem, A., Taylor, P.J., Jacobs, D., and Cotterill, F. (2017c). Neoromicia capensis. In The IUCN Red List of Threatened Species 2017: e.T44918A22048372. https://doi.org/10.2305/IUCN.UK.2017-2.RLTS. T44918A22048372.en.

Myhrman, G. (1951). Nephropathia epidemica a new infectious disease in northern Scandinavia. Acta Med. Scand. 140, 52-56.

Németh, V., Oldal, M., Madai, M., Horváth, G., Kemenesi, G., Dallos, B., Bányai, K., and Jakab, F. (2013). Molecular characterization of Dobrava and Kurkino genotypes of Dobrava-Belgrade hantavirus detected in Hungary and Northern Croatia. Virus Genes 47, 546-549. https:// doi.org/10.1007/s11262-013-0963-6.

Nemirov, K., Vapalahti, O., Lundkvist, A., Vasilenko, V., Golovljova, I., Plyusnina, A., Niemimaa, J., Laakkonen, J., Henttonen, H., Vaheri, A., and Plyusnin, A. (1999). Isolation and characterization of Dobrava hantavirus carried by the striped field mouse (Apodemus agrarius) in Estonia. J. Gen. Virol. 80, 371-379. https://doi. org/10.1099/0022-1317-80-2-371.

Nerurkar, V.R., Song, K.-J., Gajdusek, D.C., and Yanagihara, R. (1993). Genetically distinct hantavirus in deer mice. Lancet 342, 1058-1059.

Nichol, S.T., Spiropoulou, C.F., Morzunov, S., Rollin, P.E., Ksiazek, T.G., Feldmann, H., Sanchez, A., Childs, J.,
Zaki, S., and Peters, C.J. (1993). Genetic identification of a hantavirus associated with an outbreak of acute respiratory illness. Science 262, 914-917.

Noh, J.Y., Cheong, H.J., Song, J.Y., Kim, W.J., Song, K.-J., Klein, T.A., Lee, S.H., Yanagihara, R., and Song, J.-W. (2013). Clinical and molecular epidemiological features of hemorrhagic fever with renal syndrome in Korea over a 10-year period. J. Clin. Virol. 58, 11-17. https://doi. org/10.1016/j.jcv.2013.06.027.

Obiegala, A., Albrecht, C., Dafalla, M., Drewes, S., Oltersdorf, C., Turni, H., Imholt, C., Jacob, J., WagnerWiening, C., Ulrich, R.G., and Pfeffer, M. (2017). Leptospira spp. in small mammals from areas with low and high human hantavirus incidences in south-west Germany. Vector Borne Zoonotic Dis. 17, 312-318. https://doi.org/10.1089/vbz.2016.2036.

Padula, P.J., Edelstein, A., Miguel, S.D., López, N.M., Rossi, C.M., and Rabinovich, R.D. (1998). Hantavirus pulmonary syndrome outbreak in Argentina: molecular evidence for person-to-person transmission of Andes virus. Virology 241, 323-330. https://doi.org/10.1006/ viro.1997.8976.

Pattamadilok, S., Lee, B.H., Kumperasart, S., Yoshimatsu, K., Okumura, M., Nakamura, I., Araki, K., Khoprasert, Y., Dangsupa, P., Panlar, P., Jandrig, B., Krüger, D.H., Klempa, B., Jäkel, T., Schmidt, J., Ulrich, R., Kariwa, H., and Arikawa, J. (2006). Geographical distribution of hantaviruses in Thailand and potential human health significance of Thailand virus. Am. J. Trop. Med. Hyg. 75, 994-1002.

Plyusnin, A., Vapalahti, O., Lankinen, H., Lehväslaiho, H., Apekina, N., Myasnikov, Y., Kallio-Kokko, H., Henttonen, H., Lundkvist, A., Brummer-Korvenkontio, M., Gavrilovskaya, I., and Vaheri, A. (1994). Tula virus: a newly detected hantavirus carried by European common voles. J. Virol. 68, 7833-7839.

Plyusnin, A., Vapalahti, O., and Vaheri, A. (1996). Hantaviruses: genome structure, expression and evolution. J. Gen. Virol. 77, 2677-2687. https://doi. org/10.1099/0022-1317-77-11-2677.

Plyusnina, A., Ibrahim, I.N., and Plyusnin, A. (2009). A newly recognized hantavirus in the Asian house rat (Rattus tanezumi) in Indonesia. J. Gen. Virol. 90, 205209. https://doi.org/10.1099/vir.0.006155-0.

Polat, C., Ergünay, K., Irmak, S., Erdin, M., Brinkmann, A., Çetintaş, O., Çoğal, M., Sözen, M., Matur, F., Nitsche, A., and Öktem, İ.M.A. (2018). A novel genetic lineage of Tula orthohantavirus in Altai voles (Microtus obscurus) from Turkey. Infect. Genet. Evol. 67, 150-158. https:// doi.org/10.1016/j.meegid.2018.11.015.

Pounder, K.C., Begon, M., Sironen, T., Henttonen, H., Watts, P.C., Voutilainen, L., Vapalahti, O., Klempa, B., Fooks, A.R., and McElhinney, L.M. (2013). Novel hantavirus in field vole, United Kingdom. Emerg. Infect. Dis. 19, 673-675. https://doi.org/10.3201/eid1904.121057.

Powell, G.M. (1954). Hemorrhagic fever: a study of 300 cases. Medicine (Baltimore) 33, 97-153.

Powers, A.M., Mercer, D.R., Watts, D.M., Guzman, H., Fulhorst, C.F., Popov, V.L., and Tesh, R.B. (1999). Isolation and genetic characterization of a hantavirus (Bunyaviridae: Hantavirus) from a rodent, Oligoryzomys microtis (Muridae), collected in northeastern Peru. Am. J. Trop. Med. Hyg. 61, 92-98. 
Quan, P.L., Junglen, S., Tashmukhamedova, A., Conlan, S., Hutchison, S.K., Kurth, A., Ellerbrok, H., Egholm, M., Briese, T., Leendertz, F.H., and Lipkin, W.I. (2010). Moussa virus: a new member of the Rhabdoviridae family isolated from Culex decens mosquitoes in Côte d'Ivoire. Virus Res. 147, 17-24. doi:10.1016/j. virusres.2009.09.013.

Radosa, L., Schlegel, M., Gebauer, P., Ansorge, H., Heroldová, M., Jánová, E., Stanko, M., Mošanský, L., Fričová, J., Pejčoch, M., Suchomel, J., Purchart, L., Groschup, M.H., Krüger, D.H., Ulrich, R.G., and Klempa, B. (2013). Detection of shrew-borne hantavirus in Eurasian pygmy shrew (Sorex minutus) in Central Europe. Infect. Genet. Evol. 19, 403-410. https://doi. org/10.1016/j.meegid.2013.04.008.

Raharinosy, V., Olive, M.M., Andriamiarimanana, F.M., Andriamandimby, S.F., Ravalohery, J.P., Andriamamonjy, S., Filippone, C., Rakoto, D.A.D., Telfer, S., and Heraud, J.M. (2018). Geographical distribution and relative risk of Anjozorobe virus (Thailand orthohantavirus) infection in black rats (Rattus rattus) in Madagascar. Virol. J. 15, 83. https://doi.org/10.1186/s12985-0180992-9.

Ramsden, C., Melo, F.L., Figueiredo, L.M., Holmes, E.C., and Zanotto, P.M., and the VGDN Consortium. (2008). High rates of molecular evolution in hantaviruses. Mol. Biol. Evol. 25, 1488-1492. https://doi.org/10.1093/ molbev/msn093.

Ramsden, C., Holmes, E.C., and Charleston, M.A. (2009). Hantavirus evolution in relation to its rodent and insectivore hosts: no evidence for codivergence. Mol. Biol. Evol. 26, 143-153. https://doi.org/10.1093/ molbev/msn234.

Resman, K., Korva, M., Fajs, L., Zidarič, T., Trilar, T., and Županc, T.A. (2013). Molecular evidence and high genetic diversity of shrew-borne Seewis virus in Slovenia. Virus Res. 177, 113-117. https://doi.org/10.1016/j. virusres.2013.07.011.

Reynes, J.M., Razafindralambo, N.K., Lacoste, V., Olive, M.M., Barivelo, T.A., Soarimalala, V., Heraud, J.M., and Lavergne, A. (2014). Anjozorobe hantavirus, a new genetic variant of Thailand virus detected in rodents from Madagascar. Vector Borne Zoonotic Dis. 14, 212-219. https://doi.org/10.1089/vbz.2013.1359.

Rollin, P.E., Ksiazek, T.G., Elliott, L.H., Ravkov, E.V., Martin, M.L., Morzunov, S., Livingstone, W., Monroe, M., Glass, G., Ruo, S., Khan, A.S., Childs, J.E., Nichol, S.T., and Peters, C.J. (1995). Isolation of Black Creek Canal virus, a new hantavirus from Sigmodon hispidus in Florida. J. Med. Virol. 46, 35-39.

Ruedas, L.A., Salazar-Bravo, J., Tinnin, D.S., Armién, B., Cáceres, L., García, A., Díaz, M.A., Gracia, F., Suzán, G., Peters, C.J., Yates, T.L., and Mills, J.N. (2004). Community ecology of small mammal populations in Panamá following an outbreak of hantavirus pulmonary syndrome. J. Vector Ecol. 29, 177-191.

Sabino-Santos, G., Jr., Maia, F.G.M., Martins, R.B., Gagliardi, T.B., Souza, W.M., Muylaert, R.L., Luna, L.K.S., Melo, D.M., Cardoso, R.S., Barbosa, N.D.S., Pontelli, M.C., Mamani-Zapana, P.R., Vieira, T.M., Melo, N.M., Jonsson, C.B., Goodin, D., Salazar-Bravo, J., daSilva, L.L.P., Arruda, E., and Figueiredo, L.T.M. (2018). Natural infection of Neotropical bats with hantavirus in Brazil. Sci. Rep. 13, 9018. https://doi.org/10.1038/ s4159-018-27442-w.

Schlegel, M., Kindler, E., Essbauer, S.S., Wolf, R., Thiel, J., Groschup, M.H., Heckel, G., Oehme, R.M., and Ulrich, R.G. (2012a). Tula virus infections in the Eurasian water vole in Central Europe. Vector Borne Zoonotic Dis. 12, 503-513. https://doi.org/10.1089/vbz.2011.0784.

Schlegel, M., Radosa, L., Rosenfeld, U.M., Schmidt, S., Triebenbacher, C., Löhr, P.W., Fuchs, D., Heroldová, M., Jánová, E., Stanko, M., Mošanský, L., Fričová, J., Pejčoch, M., Suchomel, J., Purchart, L., Groschup, M.H., Krüger, D.H., Klempa, B., and Ulrich, R.G. (2012b). Broad geographical distribution and high genetic diversity of shrew-borne Seewis hantavirus in Central Europe. Virus Genes 45, 48-55. https://doi.org/10.1007/s11262012-0736-7.

Schmidt-Chanasit, J., Essbauer, S., Petraityte, R., Yoshimatsu, K., Tackmann, K., Conraths, F.J., Sasnauskas, K., Arikawa, J., Thomas, A., Pfeffer, M., Scharninghausen, J.J., Splettstoesser, W., Wenk, M., Heckel, G., and Ulrich, R.G. (2010). Extensive host sharing of central European Tula virus. J. Virol. 84, 459-474. https://doi. org/10.1128/JVI.01226-09.

Shi, M., Lin, X.-D., Chen, X., Tian, J.-H., Chen, L.-J., Li, K., Wang, W., Eden, J.-S., Shen, J.-J., Liu, L., Holmes, E.C., and Zhang, Y.-Z. (2018). The evolutionary history of vertebrate RNA viruses. Nature 556, 197-202. https:// doi.org/10.1038/s41586-018-0012-7.

Smadel, J.E. (1953). Epidemic hemorrhagic fever. Am. J. Public Health Nations Health 43, 1327-1330.

Song, J.-W., Baek, L.J., Gajdusek, D.C., Yanagihara, R., Gavrilovskaya, I., Luft, B.J., Mackow, E.R., and Hjelle, B. (1994). Isolation of pathogenic hantavirus from whitefooted mouse (Peromyscus leucopus). Lancet 344, 1637.

Song, J.-W., Gligić, A., and Yanagihara, R. (2002). Identification of Tula hantavirus in Pitymys subterraneus captured in the Cacak region of Serbia-Yugoslavia. Int. J. Infect. Dis. 6, 31-36.

Song, J.-W., Baek, L.J., Song, K.-J., Skrok, A., Markowski, J., Bratosiewicz, J., Kordek, R., Liberski, P.P., and Yanagihara, R. (2004). Characterization of Tula virus from common voles (Microtus arvalis) in Poland: evidence for geographic-specific phylogenetic clustering. Virus Genes 29, 239-247. https://doi.org/10.1023/ B:VIRU.0000036384.50102.cf.

Song, J.-W., Baek, L.J., Schmaljohn, C.S., and Yanagihara, R. (2007a). Thottapalayam virus, a prototype shrewborne hantavirus. Emerg. Infect. Dis. 13, 980-985. https://doi. org/10.3201/eid1307.070031.

Song, J.-W., Gu, S.H., Bennett, S.N., Arai, S., Puorger, M., Hilbe, M., and Yanagihara, R. (2007b). Seewis virus, a genetically distinct hantavirus in the Eurasian common shrew (Sorex araneus). Virol. J. 4, 114. https://doi. org/10.1186/1743-422X-4-114.

Song, J.-W., Kang, H.J., Song, K.-J., Truong, T.T., Bennett, S.N., Arai, S., Truong, N.U., and Yanagihara, R. (2007c). Newfound hantavirus in Chinese mole hantavirus in Chinese mole shrew, Vietnam. Emerg. Infect. Dis. 13, 1784-1787. https://doi.org/10.3201/eid1311.070492.

Song, J.-W., Kang, H.J., Gu, S.H., Moon, S.S., Bennett, S.N., Song, K.-J., Baek, L.J., Kim, H.C., O’Guinn, M.L., Chong, S.T., Klein, T.A., and Yanagihara, R. (2009). Characterization of Imjin virus, a newly isolated 
hantavirus from the Ussuri white-toothed shrew (Crocidura lasiura). J Virol. 83, 6184-6191. https://doi. org/10.1128/JVI.00371-09.

Song, K.-J., Baek, L.J., Moon, S.S., Ha, S.J., Kim, S.H., Park, K.S., Klein, T.A., Sames, W., Kim, H.-C., Lee, J.S., Yanagihara, R., and Song, J.-W. (2007). Muju virus, a newfound hantavirus harbored by the arvicolid rodent Myodes regulus in Korea. J. Gen. Virol. 88, 3121-3129. https://doi.org/10.1099/vir.0.83139-0.

Song, W., Torrez-Martinez, N., Irwin, W., Harrison, F.J., Davis, R., Ascher, M., Jay, M., and Hjelle, B. (1995). Isla Vista virus: a genetically novel hantavirus of the California vole Microtus californicus. J. Gen. Virol. 76, 3195-3199. https://doi.org/10.1099/0022-1317-7612-3195.

Straková, P., Dufkova, L., Širmarová, J., Salát, J., Bartonička, T., Klempa, B., Pfaff, F., Höper, D., Hoffmann, B., Ulrich, R.G., and Růžek, D. (2017). Novel hantavirus identified in European bat species Nyctalus noctula. Infect. Genet. Evol. 48, 127-130. https://doi.org/10.1016/j. meegid.2016.12.025.

Sumibcay, L., Kadjo, B., Gu, S.H., Kang, H.J., Lim, B.K., Cook, J.A., Song, J.-W., and Yanagihara, R. (2012). Divergent lineage of a novel hantavirus in the banana pipistrelle (Neoromicia nanus) in Côte d'Ivoire. Virol. J. 9, 34. https://doi.org/10.1186/1743-422X-9-34.

Suzuki, A., Bisordi, I., Levis, S., Garcia, J., Pereira, L.E., Souza, R.P., Sugahara, T.K., Pini, N., Enria, D., and Souza, L.T. (2004). Identifying rodent hantavirus reservoirs, Brazil. Emerg. Infect. Dis. 10, 2127-2134. https://doi.org/10.3201/eid1012.040295.

Teeling, E.C. (2009). Bats (Chiroptera). In The Timetree of Life, S.B. Hedges and S. Kumar, eds. (Oxford, UK: Oxford University Press), pp. 499-503.

Těšíková, J., Bryjová, A., Bryja, J., Lavrenchenko, L.A., and Goüy de Bellocq, J. (2017). Hantavirus strains in East Africa related to Western African hantaviruses. Vector Borne Zoonotic Dis. 17, 278-280. https://doi. org/10.1089/vbz.2016.2022.

Tkachenko, E.A., Ivanov, A.P., Donets, M.A., Miasnikov, Y.A., Ryltseva, E.V., Gaponova, L.K., Bashkirtsev, V.N., Okulova, N.M., Drozdov, S.G., Slonova, R.A., Somov, G.P., and Astakhova, T.I. (1983). Potential reservoir and vectors of haemorrhagic fever with renal syndrome (HFRS) in the U.S.S.R. Ann. Soc. Belg. Med. Trop. 63, 267-269.

Toro, J., Vega, J.D., Khan, A.S., Mills, J.N., Padula, P., Terry, W., Yadón, Z., Valderrama, R., Ellis, B.A., Pavletic, C., Cerda, R., Zaki, S., Shieh, W.J., Meyer, R., Tapia, M., Mansilla, C., Baro, M., Vergara, J.A., Concha, M., Calderon, G., Enria, D., Peters, C.J., and Ksiazek, T.G. (1998). An outbreak of hantavirus pulmonary syndrome, Chile, 1997. Emerg. Infect. Dis. 4, 687-694. https://doi.org/10.3201/eid0404.980425.

Torrez-Martinez, N., and Hjelle, B. (1995). Enzootic of Bayou hantavirus in rice rats (Oryzomys palustris) in 1983. Lancet 346, 780-781.

Tsai, T.F. (1987). Hemorrhagic fever with renal syndrome: mode of transmission to humans. Lab. Anim. Sci. 37, $428-430$.

Tu, V.T., Csorba, G., Görföl, T., Arai, S., Son, N.T., Thanh, H.T., and Hasanin, A. (2015). Description of a new species of the genus Aselliscus (Chiroptera, Hipposideridae) from
Vietnam. Acta Chiropterolog. 17, 233-254. https://doi. org/10.3161/15081109ACC2015.17.2.002.

Vaheri, A., Henttonen, H., Voutilainen, L., Mustonen, J., Sironen, T., and Vapalahti, O. (2013). Hantavirus infections in Europe and their impact on public health. Rev. Med. Virol. 23, 35-49. https://doi.org/10.1002/ rmv.1722.

Vapalahti, K., Paunio, M., Brummer-Korvenkontio, M., Vaheri, A., and Vapalahti, O. (1999). Puumala virus infection in Finland: increased occupational risk for farmers. Am. J. Epidemiol. 149, 1142-1151.

Vapalahti, O., Plyusnin, A., Vaheri, A., and Henttonen, H. (1995). Hantavirus antibodies in European mammalogists. Lancet 345, 1569.

Vitek, C.R., Ksiazek, T.G., Peters, C.J., and Breiman, R.F. (1996). Evidence against infection with hantaviruses among forest and park workers in the southwestern United States. Clin. Infect. Dis. 23, 283-285.

Walston, J., Kingston, T., and Hutson, A.M. (2008). Rhinolophus affinis. In The IUCN Red List of Threatened Species 2008: e.T19522A8952553. https: / / doi.org/10.2305/IUCN.UK.2008.RLTS. T19522A8952553.en.

Wang, C.Q. Gao, J.H., Li, M., Guo, W.P., Lu, M.Q. Wang, W., Hu, M.X., Li, M.H., Yang, J., Liang, H.J., Tian, X.F., Holmes, E.C., and Zhang, Y.Z. (2014). Co-circulation of Hantaan, Kenkeme, and Khabarovsk hantaviruses in Bolshoy Ussuriysky Island, China. Virus Res. 191, 51-58. https://doi.org/10.1016/j.virusres.2014.07.021.

Wang, H., Yoshimatsu, K., Ebihara, H., Ogino, M., Araki, K., Kariwa, H., Wang, Z., Luo, Z., Li, D., Hang, C., and Arikawa, J. (2000). Genetic diversity of hantaviruses isolated in China and characterization of novel hantaviruses isolated from Niviventer confucianus and Rattus rattus. Virology 278, 332-345. https://doi. org/10.1006/viro.2000.0630.

Weiss, S., Witkowski, P.T., Auste, B., Nowak, K., Weber, N., Fahr, J., Mombouli, J.V., Wolfe, N.D., Drexler, J.F., Drosten, C., Klempa, B., Leendertz, F.H., and Krüger, D.H. (2012). Hantavirus in bat, Sierra Leone. Emerg. Infect. Dis. 18, 159-161. https://doi.org/10.3201/ eid1801.111026.

Witkowski, P.T., Drexler, J.F., Kallies, R., Lickova, M., Bokorova, S., Mananga, G.D., Szemes, T., Leroy, E.M., Krüger, D.H., Drosten, C., and Klempa, B. (2016). Phylogenetic analysis of a newfound bat-borne hantavirus supports a laurasiatherian host association for ancestral mammalian hantaviruses. Infect. Genet. Evol. 41, 113-119. https://doi.org/10.1016/j. meegid.2016.03.036.

Woolhouse, M.E.J., and Gowtage-Sequeria, S. (2005). Host range and emerging and reemerging pathogens. Emerg. Infect. Dis. 11, 1842-1847. https://doi.org/10.3201/ eid1112.050997.

Wróblewska-Łuczka, P., Chmielewska-Badora, J., Zwoliński, J., Galínska, E.M., Adamczuk, P., Żukiewicz-Sobczak, W., Zagórski, J., and Wojtvła, A. (2017). Seroepidemiologic evaluation of exposure to infection with hantavirus (serotype Puumala) among forestry workers in Poland. Baltic Forestry 23, 612-618.

Wróblewska-Łuczkawroblewska, P., Chmielewska-Badora, J.,Zwoliński,J., Galińska, E.M., Adamczuk, P., ŻukiewiczSobczak, W., Zagórski, J., Tomasiewicz, K., and Wojtyła, 
A. (2017). Exposure to infection with Hantavirus (serotype Dobrava/Hantaan) among forestry workers in Poland. Folia Forestalia Polonica. Seria A - Forestry 59, 198-206. https://doi.org/10.1515/ffp-2017-0021.

Xu, L., Wu, J., He, B., Qin, S., Xia, L., Qin, M., Li, N., and Tu, C. (2015). Novel hantavirus identified in black-bearded tomb bats, China. Infect. Genet. Evol. 31, 158-160. https://doi.org/10.1016/j.meegid.2015.01.018.

Xu, L., Wu, J., Li, Q. Wei, Y., Tan, Z., Cai, J., Guo, H., Yang, L., Huang, X., Chen, J., Zhang, F., He, B., and Tu, C. (2019). Seroprevalence, cross antigenicity and circulation sphere of bat-borne hantaviruses revealed by serological and antigenic analyses. PLoS Pathog. 15, e1007545. https:// doi.org/10.1371/journal.ppat.1007545.

Yadav, P.D., Vincent, M.J., and Nichol, S.T. (2007). Thottapalayam virus is genetically distant to the rodentborne hantaviruses, consistent with its isolation from the Asian house shrew (Suncus murinus). Virol. J. 4, 80. https://doi.org/10.1186/1743-422X-4-80.

Yanagihara, R., Gajdusek, D.C., Gibbs, C.J., Jr., and Traub, R. (1984). Prospect Hill virus: serological evidence for infection in mammalogists. N. Engl. J. Med. 310, 1325-1326. https://doi.org/10.1056/ NEJM198405173102013.

Yanagihara, R., and Gajdusek, D.C. (1988). Hemorrhagic fever with renal syndrome: a historical perspective and review of recent advances. In CRC Handbook of Viral and Rickettsial Hemorrhagic Fevers, J.H.S. Gear, ed. (Boca Raton, Florida: CRC Press, Inc.), pp. 155-181.

Yanagihara, R. (1990). Hantavirus infection in the United States: epizootiology and epidemiology. Rev. Infect. Dis. 12, 449-457.

Yanagihara, R., Gu, S.H., Arai, S., Kang, H.J., and Song, J.-W. (2014). Hantaviruses: rediscovery and new beginnings. Virus Res. 187, 6-14. https://doi.org/10.1016/j. virusres.2013.12.038.
Yanagihara, R., Gu, S.H., and Song, J.-W. (2015). Expanded host diversity and global distribution of hantaviruses: implications for identifying and investigating previously unrecognized hantaviral diseases. In Global Virology Identifying and Investigating Viral Diseases, P. Shapshak, J.T. Sinnott, C. Somboonwit, and J. Kuhn, eds. (New York: Springer Publishing Company), pp. 161-198.

Yashina, L., Mishin, V., Zdanovskaya, N., Schmaljohn, C., and Ivanov, L. (2001). A newly discovered variant of a hantavirus in Apodemus peninsulae, far Eastern Russia. Emerg. Infect. Dis. 7, 912-913. https://doi. org/10.3201/eid0705.017530.

Yashina, L., Abramov, S., Gutorov, V., Dupal, T., Krivopalov, A., Panov, V., Danchinova, G., Vinogradov, V., Luchnikova, E., Hay, J., Kang, H.J., and Yanagihara, R. (2010). Seewis virus: phylogeography of a shrewborne hantavirus in Siberia, Russia. Vector-Borne Zoonotic Dis. 10, 585-591. https://doi.org/10.1089/ vbz.2009.0154.

Yashina, L.N., Abramov, S.A., Dupal, T.A., Danchinova, G.A., Malyshev, B.S., Hay, W., Gu, S.H., and Yanagihara, R. (2015). Hokkaido genotype of Puumala virus in the grey red-backed vole (Myodes rufocanus) and northern red-backed vole (Myodes rutilus) in Siberia. Infect. Genet. Evol. 33, 304-313. https://doi.org/10.1016/j. meegid.2015.05.021.

Zou, L.X., Chen, M.J., and Sun, L. (2016). Haemorrhagic fever with renal syndrome: literature review and distribution analysis in China. Int. J. Infect. Dis. 43, 95-100. https://doi.org/10.1016/j.ijid.2016.01.003.

Zuo, S.Q. Gong, Z.D., Fang, L.Q. Jiang, J.F., Zhang, J.S., Zhao, Q.M., and Cao, W.C. (2014). A new hantavirus from the stripe-backed shrew (Sorex cylindricauda) in the People's Republic of China. Virus Res. 184, 82-86. https://doi.org/10.1016/j.virusres.2014.02.004. 